\title{
Article \\ Characterization of Nonconventional Food Plants Seeds Guizotia abyssinica (L.f.) Cass., Panicum miliaceum L., and Phalaris canariensis L. for Application in the Bakery Industry
}

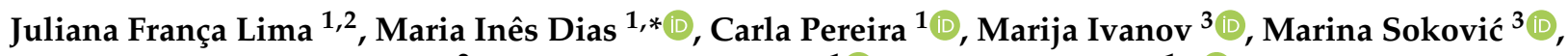 \\ Nádia Cristiane Steinmacher ${ }^{2}$, Isabel C. F. R. Ferreira ${ }^{1}$ (D) and Lillian Barros ${ }^{1, *(D)}$ \\ 1 Centro de Investigação de Montanha (CIMO), Instituto Politécnico de Bragança, Campus de Santa Apolónia, \\ 5300-253 Bragança, Portugal; julianafrancalima@hotmail.com.br (J.F.L.); carlap@ipb.pt (C.P.); \\ iferreira@ipb.pt (I.C.F.R.F.) \\ 2 Departamento Acadêmico de Alimentos (DAALM), Campus Medianeira, Universidade Tecnológica Federal \\ do Paraná, Medianeira 85884-000, PR, Brazil; nadiac@professores.utfpr.edu.br \\ 3 Department of Plant Physiology, Institute for Biological Research "Siniša Stankovi'c", University of Belgrade, \\ Bulevar Despota Stefana 142, 11000 Belgrade, Serbia; marija.smiljkovic@ibiss.bg.ac.rs (M.I.); \\ mris@ibiss.bg.ac.rs (M.S.) \\ * Correspondence: maria.ines@ipb.pt (M.I.D.); lillian@ipb.pt (L.B.); Tel.: +351-273-330-903 (M.I.D.)
}

Citation: Lima, J.F.; Dias, M.I.; Pereira, C.; Ivanov, M.; Soković, M.; Steinmacher, N.C.; Ferreira, I.C.F.R.; Barros, L. Characterization of Nonconventional Food Plants Seeds Guizotia abyssinica (L.f.) Cass., Panicum miliaceum L., and Phalaris canariensis L. for Application in the Bakery Industry. Agronomy 2021, 11, 1873. https://doi.org/10.3390/ agronomy11091873

Academic Editors: Gerardo Fernández Barbero and Sanja Cavar Zeljkovic

Received: 16 August 2021 Accepted: 13 September 2021 Published: 17 September 2021

Publisher's Note: MDPI stays neutral with regard to jurisdictional claims in published maps and institutional affiliations.

Copyright: (c) 2021 by the authors. Licensee MDPI, Basel, Switzerland. This article is an open access article distributed under the terms and conditions of the Creative Commons Attribution (CC BY) license (https:// creativecommons.org/licenses/by/ $4.0 /)$.

\begin{abstract}
Consumers have given preferences to food products that, in addition to the nutritional properties, also present bioactive characteristics with beneficial health effects. The use of Nonconventional Food Plants (NCFP) has been an asset for the food industry, not only due to its abundance but, also, because it does not compete with other vegetable matrices used for human consumption for its nutritional properties, chemical and bioactive potentiality. The present work aimed to study the granulometry and water absorption index of three seeds of unconventional food plants: niger, millet and birdseed, followed by their nutritional value, content in free sugars, fatty acids, organic acids, tocopherols and phenolic compounds by chromatographic methods and, also, the evaluation of the antioxidant, hepatotoxic and antimicrobial potential in their hydroethanolic extracts. Bakery products were developed with a partial replacement of wheat flour, using the centroid simplex method to understand the effect of applying NCFP flours in the final physical-chemical characteristics. The high granulometry associated with the high water absorption index indicates that the use of NCFP flours would have to be complemented with other flours for baking. The chemical composition of niger seed stood out the most; however, all seeds presented relatively low $\mathrm{IC}_{50}$ and $\mathrm{MIC}$ values for the inhibition of lipid peroxidation and antimicrobial activity, respectively. Finally, breads made with a mixture of millet and birdseed flour showed the greatest similarity to the control bread. Considering their composition in bioactive compounds, the use of these seeds is highly advisable in the context of a fortified diet, being sources of compounds of high nutritional value and with beneficial health effects for the final consumer.
\end{abstract}

Keywords: nonconventional food plants (NCFP); nutritional value; chemical characterization; bioactive properties; bakery products; experimental design

\section{Introduction}

Nonconventional Food Plants (NCFP) are a group of plants not usually appreciated by the consumers but are considered food, since one or more of its parts can be used for human nutrition, normally presenting very interesting bioactive and nutritional properties and, also, a low toxicity, and on which the scientific community is focusing, with particular attention to wild species [1]. The introduction of NCFP in a regular diet could lead to a diversification and improvement of its nutritional quality [2]. Due to the great potential of NCFP, their applicability in food products is unlimited, the bakery industry being one of the many areas to be addressed for the application of these plants-in particular, their 
seeds, since they present a wide variety of products based entirely on the use of seeds transformed into flour, a great flexibility in the modification of formulations and, also, due to the transversal consumer age groups that form a perfect market niche for the development of new food products [3].

Guizotia abyssinica (L.f.) Cass, commonly known as niger, is cultivated mainly for its high content in lipid compounds [4] and is considered one of the oilseeds with greater commercial importance, being cultivated in many tropical and temperate countries [5]. Panicum miliaceum L., mainly called millet, is one of the most-used ancient cereals, only behind wheat and barley, and its seed is normally used in animal feed [6]. Phalaris canariensis L. seed, better known as bird seed, is mainly used for poultry consumption; however, it was approved for human consumption in 2015 [7]. P. canariensis seed has a high composition in essential amino acids, micronutrients and fatty acids, with a predominance of linoleic, oleic and palmitic acids [7,8]. It is also a rich source of phenolic and carotenoid compounds [9], demonstrating antioxidant and antibacterial potential [10]. The profile of G. abyssinica seeds is very similar to those of cardamom, saffron and sunflowers, having a high fatty acid content [4,11] and a good source of tocopherols [11]. It also presents a high antioxidant, antimicrobial and antiviral capacity and can act in the prevention of several diseases [12,13]. P. miliaceum is described as a good source of fatty acids, predominantly linoleic acid [14], and, also, a good source of antioxidant compounds, such as phenolic acids and glycosylated flavonoids, known for their prebiotic capabilities [15].

There are very few studies of the full characterization and application of the seeds of G. abyssinica, P. miliaceum L. and P. canariensis $[5,8,16,17]$. Therefore, this study aims to contribute to the development of new bakery products, enriching the knowledge of the bakery industry as, also, the range of products to be supplied to the final consumer. For this, an integrative and in-depth study was carried out on the physical, nutritional, chemical and bioactive properties of three NCFP flours seeds. In addition, breads were developed with a partial replacement of wheat flour with the NCFP flours seeds, performing a physical, nutritional and chemical evaluation in order to understand the impact of the incorporation of NCFP flours.

\section{Materials and Methods}

\subsection{Samples and Seed Flour Preparation}

The seeds of Guizotia abyssinica (L.f.) Cass (niger), Panicum miliaceum L. (millet) and Phalaris canariensis L. (birdseed) were acquired in local trade markets in the city of Medianeira-PR/Brazil, along with the other ingredients used for producing the breads in 2019. The seed flours were prepared by freezing the seeds for $24 \mathrm{~h}$ to solidify the lipids and facilitate the processing in a knife mill (model A327R1, Moulinex, Madrid, Spain) and reduced to a fine powder with $\sim 35$ mesh (Figure 1 ). For the formulation of the breads, special wheat flour obtained from the Rio Azul Mill-PR/Brazil was used. All samples were stored in a cooler chamber protected from light until further use.

\subsection{Physical Parameters of the Flours}

To determine the size of the particles (granulometric classification), a sieve shaker (Bertel Indústria Metalúrgica Ltd.a. Caieiras, São Paulo, Brasil) was used [18]. Approximately $85 \mathrm{~g}$ of each flour was sieved for $15 \mathrm{~min}$ in a set of sieves with 20, 30, 35, 50, 60 and 100 "Mesh Tyler" (opening 850, 600, 500, 300, 250 and $150 \mu \mathrm{m}$ ) and the base. Then, the amount retained in each sieve and base were weighed and expressed in percentages.

The Water Absorption Index (WAI) was measured according to the method described by Okezie and Bello [19], where a centrifuge tube was placed with a lid and $0.5 \mathrm{~g}$ of sample and $25 \mathrm{~mL}$ of distilled water. The tubes were homogenized for $1 \mathrm{~min}$ on a mechanical vortex shaker and then centrifuged at $5300 \times \mathrm{g}$ for $20 \mathrm{~min}$ in a Scientec $5000 \mathrm{R}$ centrifuge (CIENTEC, CT-5000, CienLab, São Paulo, Brazil). The supernatant liquid was drained carefully, and the remaining material was weighed on a semi-analytical balance (AW220 Marte, Shimadzu, Tokyo, Japan); the WAI was calculated according to the equation: 
WAI $=[$ mass of the wet sample $(\mathrm{g})-$ initial mass of the sample $(\mathrm{g})] /$ mass of the wet sample (g).

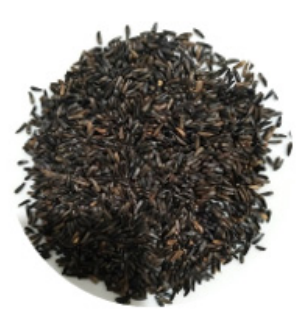

A1

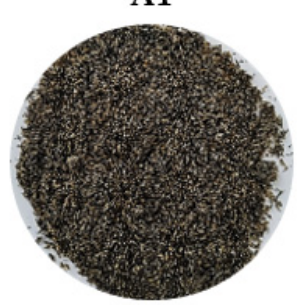

A2

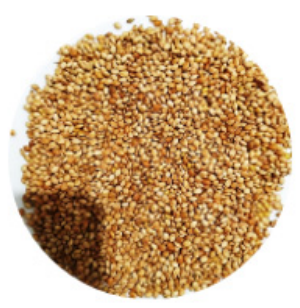

B1

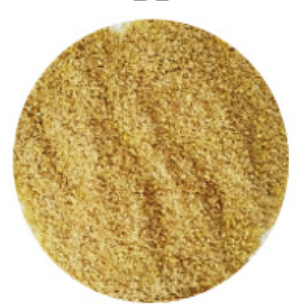

B2

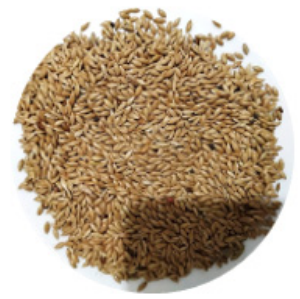

C1

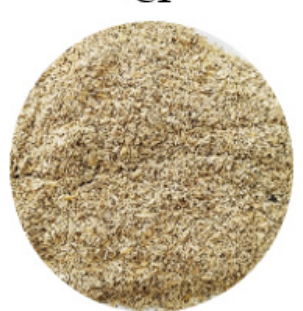

$\mathrm{C} 2$

Figure 1. Niger (A1), millet (B1) and birdseed (C1) seeds and the corresponding flours (A2, B2 and C2, respectively).

\subsection{Nutritional Profile and Chemical Composition}

\subsubsection{Moisture and Nutritional Characterization}

Moisture determination was performed using $2 \mathrm{~g}$ of each of the seed flours in the study in a digital moisture analyzer (PMB series, ae ADAM, Oxford, CT, USA) for about 7 min until complete dryness of the sample. The moisture content was determined by the weight difference of the sample and expressed as a percentage (\%).

Proteins, fat, carbohydrates and ash were determined in the seed flours using previously described AOAC analytical methods [20]. The macro-Kjeldahl method was used to determine the nitrogen content (AOAC 978.04), and the protein content was calculated as $\mathrm{N} \times 6.25$. Crude fat was determined using a Soxhlet apparatus with petroleum ether (AOAC 920.85). The ash content was determined by incineration at $600{ }^{\circ} \mathrm{C}$ until a constant mass weight was achieved (AOAC 923.03). The total carbohydrates were calculated by the difference, and the energy was calculated following the equation: Energy (kcal) $=4 \times(\mathrm{g}$ protein $)+4 \times($ g carbohydrate $)+9 \times(\mathrm{g}$ fat $)[21]$.

\subsubsection{Free Sugars}

The free sugars were also determined in the seed flours and determined by highperformance liquid chromatography coupled to a refraction index detector (HPLC-RI, Knauer, Smartline system 1000, Berlin, Germany), as previously described by the authors [22]. Sugar identification was made by comparing the relative retention times of the sample peaks with authentic standards, and quantification was performed by the internal normalization of the chromatographic peak area using melezitose (standard calibration curve: Sucrose $\left(y=0.977 x, R^{2}=0.999\right.$; LOD (Limit of detection) $=0.06 \mathrm{mg} / \mathrm{mL}$; LOQ (Limit of quantification) $=0.21 \mathrm{mg} / \mathrm{mL})$ ). The results were expressed in $\mathrm{g}$ per $100 \mathrm{~g}$ of the plant dry weight.

\subsubsection{Organic Acids}

The organic acids were analyzed by ultra-fast liquid chromatography coupled to a photodiode array detector programmed to record at $215 \mathrm{~nm}$ as the preferred wavelength (UFLC-PDA; Shimadzu Corporation, Kyoto, Japan), as previously described [22], in the seed flours. The identification and quantification of the individual organic acids was performed by comparison to authentic standards by comparison of the peak area in the 
programmed wavelength (standard calibration curves: oxalic acid $\left(y=9 \times 10^{6} x+45,973\right.$, $\left.R^{2}=0.9901, \mathrm{LOD}=6.3 \mu \mathrm{g} / \mathrm{mL} ; \mathrm{LOQ}=20.8 \mu \mathrm{g} / \mathrm{mL}\right) ;$ quinic acid $(y=610,607 x+46,061$, $\left.R^{2}=0.9995, \mathrm{LOD}=11.3 \mu \mathrm{g} / \mathrm{mL} ; \mathrm{LOQ}=37.6 \mu \mathrm{g} / \mathrm{mL}\right) ;$ shikimic acid $\left(y=7 \times 10^{7} x+175,156\right.$, $\left.R^{2}=0.9999, \mathrm{LOD}=10.2 \mu \mathrm{g} / \mathrm{mL} ; \mathrm{LOQ}=56.5 \mu \mathrm{g} / \mathrm{mL}\right)$ and fumaric acid $(y=154,862 x+1$ $\left.\times 10^{6}, R^{2}=0.9977, \mathrm{LOD}=42.5 \mu \mathrm{g} / \mathrm{mL} ; \mathrm{LOQ}=141.7 \mu \mathrm{g} / \mathrm{mL}\right)$. The results were expressed in $\mathrm{g}$ per $100 \mathrm{~g}$ of the plant dry weight.

\subsubsection{Fatty Acids}

The seed flours were also characterized in terms of the fatty acids by gas chromatography with flame ionization detection (GC-FID, DANI model GC 1000 instrument, Milan, Italy), as previously described [22]. The results were recorded and processed using Clarity Software (DataApex, Prague, The Czech Republic) and expressed as the relative percentage of each fatty acid.

\subsubsection{Tocopherols}

The extraction procedure was performed using the seed flours, and the chromatographic characterization was performed following a procedure previously described [22] An HPLC coupled to a fluorescence detector (Knauer, Smartline system 1000, Berlin, Germany) was used, and the compounds were identified by comparisons with authentic standards. The identification and quantification were based on the fluorescence signal response of each standard using the internal standard method (tocol) and by using calibration curves obtained from the commercial standards of each compound (standard calibration curves: $\alpha$-tocopherol $\left(y=1.295 x, R^{2}=0.991 ; \mathrm{LOD}=18.06 \mathrm{ng} / \mathrm{mL} ; \mathrm{LOQ}=60.20 \mathrm{ng} / \mathrm{mL}\right) ; \beta$ tocopherol $\left(y=0.396 x, R^{2}=0.992 ; \mathrm{LOD}=25.82 \mathrm{ng} / \mathrm{mL}, \mathrm{LOQ}=86.07 \mathrm{ng} / \mathrm{mL}\right) ; \gamma$-tocopherol $\left(y=0.567 x ; R^{2}=0.991 ; \mathrm{LOD}=14.79 \mathrm{ng} / \mathrm{mL}, \mathrm{LOQ}=49.32 \mathrm{ng} / \mathrm{mL}\right)$ and $\delta$-tocopherol $\left.\left(y=0.678 x ; R^{2}=0.992 ; \mathrm{LOD}=20.09 \mathrm{ng} / \mathrm{mL}, \mathrm{LOQ}=66.95 \mathrm{ng} / \mathrm{mL}\right)\right)$. The results were expressed as mg per $100 \mathrm{~g}$ of dry weight.

\subsection{Bioactivities and Phenolic Profile}

\subsubsection{Extracts Preparation}

The hydroethanolic extracts $(80: 20, v / v)$ were prepared by maceration using $1 \mathrm{~g}$ of the seed flours in $30 \mathrm{~mL}$ of solvent for $1 \mathrm{~h}$. After, they were filtered using Whatman $\mathrm{n}^{\circ}$ 4 filter paper and re-extracted using the same volume of solvent and the same time. The combined extracts were evaporated for the complete dryness of ethanol under vacuum at $50{ }^{\circ} \mathrm{C}$ using a rotary evaporator (Buchi, 3000 series, Flawil, Switzerland). The aqueous phase was frozen, lyophilized and further stored under controlled conditions of light and humidity for future analysis.

\subsubsection{Antioxidant Activity}

For this test, the three lyophilized hydroethanolic extracts were evaluated as described in detail by Reference [23]. An in vitro cell-based method evaluated the potential of the samples to inhibit the production of thiobarbituric acid reactive substances (TBARS) in brain homogenates of pigs (Sus scrofa). The results were expressed in $\mathrm{IC}_{50}$ values, which corresponded to the concentration of the extract providing 50\% antioxidant activity $(\mu \mathrm{g} / \mathrm{mL})$. The oxidative hemolysis inhibition test (OxHLIA), which is also a cell-based method described in detail by Reference [24], was also used. The results were also expressed in $\mathrm{IC}_{50}$ values $(\mu \mathrm{g} / \mathrm{mL})$, which correspond to the concentration of the extract, providing 60 min of delay in cell hemolysis $(\Delta t)$. Both trials used Trolox as the positive control.

\subsubsection{Antimicrobial Activity}

A water stock solution of $100 \mathrm{mg} / \mathrm{mL}$ of the three lyophilized extracts was prepared to perform the evaluation of the antimicrobial activity. The Gram-positive bacteria: Staphylococcus aureus (ATCC 11632), Bacillus cereus (clinical isolate) and Listeria monocytogenes (NCTC 7973), as well as the following Gram-negative bacteria: Escherichia coli (ATCC 25922), 
Salmonella ser. Typhimurium (ATCC 13311) and Enterobacter cloacae (ATCC 35030) were used in order to determine potential antibacterial activity of the samples. For antifungal assays, six micromycetes were used: Aspergillus fumigatus (human isolate), Aspergillus niger (ATCC 6275), Aspergillus versicolor (ATCC 11730), Penicillium funiculosum (ATCC 36839), Trichoderma viride (IAM 5061) and Penicillium verrucosum var cyclopium (food isolate) [24,25].

\subsubsection{Hepatotoxic Activity}

The lyophilized extracts were redissolved in water to obtain a stock solution of $8 \mathrm{mg} / \mathrm{mL}$, which was further diluted to obtain a range of six concentrations below the stock solution. A nontumor cell culture (named PLP2) was prepared from a freshly harvested porcine liver obtained from a local slaughterhouse. The sulforhodamine B assay was performed according to a procedure previously described by the authors [26]. Ellipticine was used as a positive control, and the results were expressed in $\mathrm{GI}_{50}$ values $(\mu \mathrm{g} / \mathrm{mL})$.

\subsubsection{Phenolic Profile}

The lyophilized extracts were redissolved in ethanol:water $(80: 20, v / v)$ and characterized regarding their phenolic composition using Dionex Ultimate 3000 UHPLC (Thermo Scientific, San Jose, CA, USA), as previously described by Bessada et al. [27]. Detection was performed using a diode array detector (DAD) programed at $280 \mathrm{~nm}$ and $370 \mathrm{~nm}$ as the preferred wavelengths, connected in line with a Linear Ion Trap LTQ XL mass spectrometer (Thermo Finnigan, San Jose, CA, USA) equipped with an ESI source working in negative mode. For data acquisition and analysis was used the Xcalibur ${ }^{\circledR}$ data system (Thermo Finnigan, San Jose, CA, USA). Identification of the compounds was performed through the available standard compounds and using literature information regarding UV-Vis, pseudomolecular ion and the mass fragmentation pattern. Quantification was performed using 5-level calibration curves obtained from commercial standard compounds (standard calibration curves: chlorogenic acid $\left(y=168,823 x-161,172, R^{2}=0.9999\right.$, $\mathrm{LOD}=0.20 \mu \mathrm{g} / \mathrm{mL} ; \mathrm{LOQ}=0.68 \mu \mathrm{g} / \mathrm{mL})$; caffeic acid $\left(y=388,345 x+406,369, R^{2}=0.9939\right.$, $\mathrm{LOD}=0.78 \mu \mathrm{g} / \mathrm{mL} ; \mathrm{LOQ}=1.97 \mu \mathrm{g} / \mathrm{mL})$ and apigenin-6-C-glucoside $(y=107,025 x+61,531$, $\left.\left.R^{2}=0.9989 ; \mathrm{LOD}=0.19 \mu \mathrm{g} / \mathrm{mL} ; \mathrm{LOQ}=0.63 \mu \mathrm{g} / \mathrm{mL}\right)\right)$. The results were expressed in $\mathrm{mg}$ per $g$ of extract.

\subsection{Bread Formulation}

\subsubsection{Preparation of Breads}

To prepare the breads, two formulations were made, one for the control and the other for the other samples, as shown in Table 1. A British Bakery Multipane 2P (Multipane, Britânia, Joinville, Brazil) was used, set in option II to $900 \mathrm{~g}$ and dark color with programming in cycle 11, indicated for preparing the breads with the finest and softest rinds. This option prepares the dough in the mixing stage, waits for the rest of the dough to rise and bakes the bread, totaling $3 \mathrm{~h}$ for preparing these three stages. After baking, the loaves were cold unmolded and left to stand for $1 \mathrm{~h}$.

Table 1. Formulations for the preparation of the control bread and NCFP flour-based bread.

\begin{tabular}{ccc}
\hline Ingredient & Control $(\mathbf{g})$ & $\mathbf{2 0} \% \mathbf{~ N C F P}(\mathbf{g})$ \\
\hline Wheat flour & 375.00 & 300.00 \\
NCFP flour & 0 & 75.00 \\
Water & 217.50 & 217.50 \\
Sunflower oil & 33.75 & 33.75 \\
Sugar & 22.50 & 22.50 \\
Salt & 7.50 & 7.50 \\
Dry biological yeast & 7.50 & 7.50 \\
\hline
\end{tabular}




\subsubsection{Design of Mixtures}

For the experimental design, a centroid simplex method $\{3,2\}$ was used according to Scheffé [28] augmented with interior points. The method was applied to analyze the effect of substituting wheat flour for niger, millet and birdseed flours in the bread physical attributes. According to Reference [29], each answer $(Y)$ was modeled as a function of the coded factors $\left(x_{i} ; x_{j}\right.$ and $\left.x_{k}\right)$ by the mean of the equation:

$$
Y=\sum_{i=1}^{3} \beta_{i} x_{i}+\sum \sum_{i<j}^{3} \beta_{i j} x_{i} x_{j}+\sum \sum \sum_{i<j<k}^{3} \beta_{i j k} x_{i} x_{j} x_{k}
$$

The three-component design consisted of 7 trials. The compositions were formulated using the mixture modeling methodology of experimental planning according to Calado and Montgomery [30]. The combinations of the mixtures according to the design of the flours and the added quantity of each NCFP flour were therefore: sample 1 ( $75 \mathrm{~g}$ of niger), sample 2 ( $75 \mathrm{~g}$ of millet), sample 3 (75 g of birdseed), sample 4 ( $37.5 \mathrm{~g}$ of niger and $37.5 \mathrm{~g}$ of millet), sample 5 ( $37.5 \mathrm{~g}$ of niger and $37.5 \mathrm{~g}$ of birdseed), sample 6 ( $37.5 \mathrm{~g}$ of millet and $37.5 \mathrm{~g}$ of birdseed) and sample 7 ( $25 \mathrm{~g}$ of niger, $25 \mathrm{~g}$ of millet and $25 \mathrm{~g}$ of birdseed) (Figure 2).

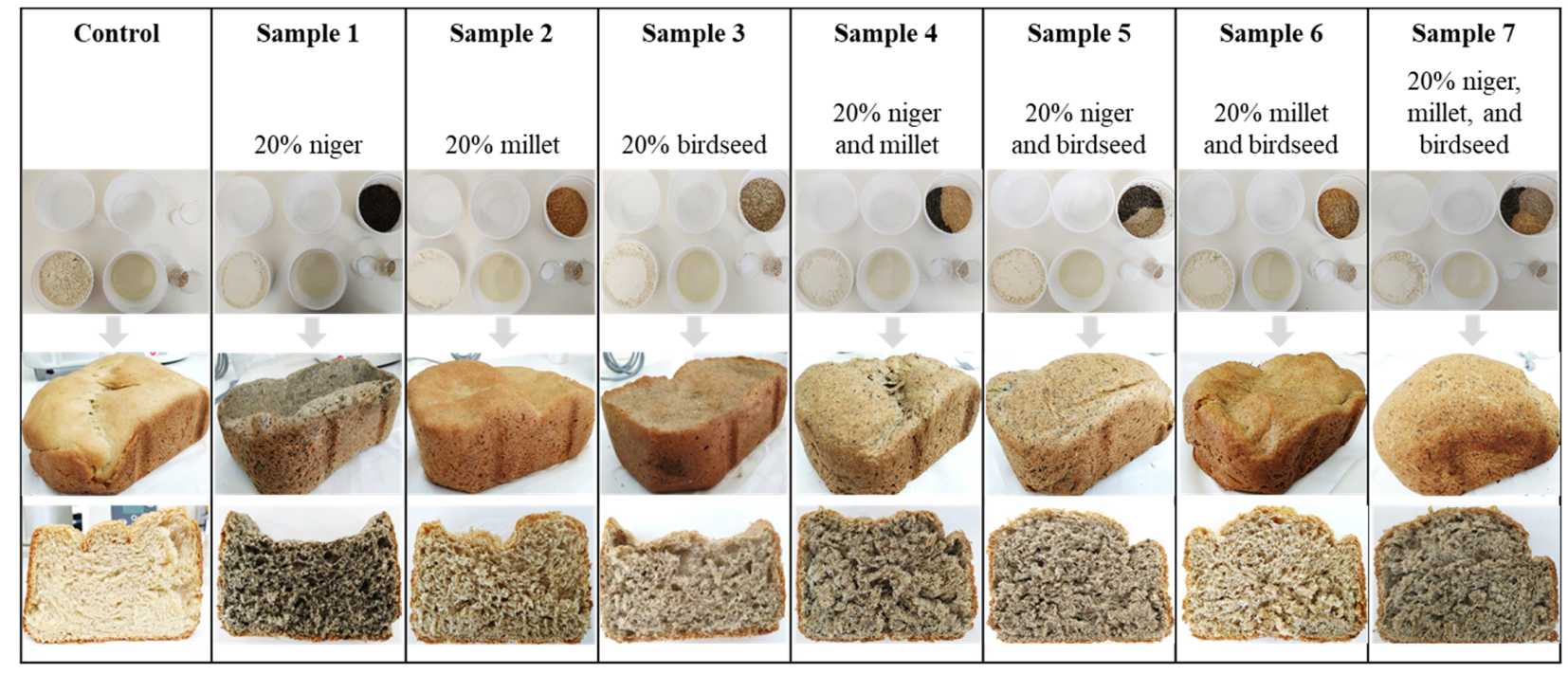

Figure 2. Combinations of the mixtures according to the design of the flours, added quantity of each NCFPs flour and exterior and interior representations of the breads obtained.

\subsubsection{Physical Characteristics of Breads}

The colorimetric test was performed on the fresh breads using the color parameters given by the Commission Internationale de L'Éclairage-CIE; these parameters are divided into three groups: $\mathrm{L}^{*}$ (lightness, 0 (black) to 100 (white)), $\mathrm{a}^{*}$ (redness to green, -60 (green) to 60 (red)) and $\mathrm{b}^{*}$ (yellow to blue, -60 (blue) to 60 (yellow)). The color was measured using the CR-400 Konica Minolta Sensing colorimeter (Osaka, Japan) on the crumbs of different slices for each bread already baked [31]. The data obtained was processed with Spectra Magic Nx software (CM-S100W 2.03.0006, Konica Minolta).

The fresh bread mass was determined on a precision scale (Bivolt BL3200H, Shimadzu, Barueri-SP-Brazil) and expressed in grams, the total volume (VT) obtained by the method of seed displacement [32] and the specific volume (VE) by dividing the volume of the bread $\left(\mathrm{cm}^{3}\right)$ for its dough after baking $(\mathrm{g})$.

The texture analysis of the fresh breads was performed after baking by the crumb compression test [32]. A TA.XT.plus texturometer (Stable Micro Systems, Surrey, UK) was used, equipped with a 5-kg loading cell and a 36-mm-diameter cylindrical probe. The 
parameters used were the pretest speed: $1 \mathrm{~mm} / \mathrm{s}$, test speed: $1.7 \mathrm{~mm} / \mathrm{s}$, post-test speed: $10 \mathrm{~mm} / \mathrm{s}$, compression depth: $40 \%$ and slice thickness: $25 \mathrm{~mm}$.

\subsubsection{Nutritional Profile and Chemical Characterization of the Obtained Breads}

The bread samples were frozen, lyophilized and reduced to a fine, dried power for the following analysis. Moisture, proteins, fat, carbohydrates and ash were determined following the previously described methods in Section 2.3.1 of the present manuscript. For the free sugars, organic acids and fatty acids profile determination, the previously described methods in Sections 2.3.2-2.3.4, respectively, of the present manuscript were used.

\subsection{Statistical Analysis}

Three samples were used for each assay. All the assays were carried out in triplicate. The results were expressed as mean values with standard deviations (SD). The results were analyzed using one-way analysis of variance (ANOVA) followed by Tukey's HSD Test with $p=0.05$ using IBM SPSS Statistics for Windows, Version 23.0 (IBM Corp., Armonk, NY, USA) and were expressed as the mean values and standard deviation (SD).

\section{Results and Discussion}

Grains and seeds, in their natural form or processed (flours, for instance), are among the most widely consumed group of products of vegetable origin [33]. A study performed by Biswas and Rahmatullah [34] showed that, in a period of food scarcity, the NCFP are a viable and efficient alternative to replace the food products we consume today. In the following discussion, a detailed description of the physical, nutritional, chemical and bioactive characteristics of NCPFs seeds are presented, complemented with a case study on supplemented breads, in order to understand how these seeds contribute to the final product. Since it was not possible to present the variety of the three plants studied, all comparisons performed with other studies throughout the discussion of the results are merely qualitative; the edaphic-climatic and geographic conditions of the plants greatly influence their entire nutritional and chemical composition and, consequently, their bioactive properties.

\subsection{Physical Characteristics of the Three Seed Flours Samples}

The results referring to the granulometry of the particles of the flours obtained from niger, millet and birdseed are presented in Table 2. According to Silva et al. [35], the granulometry study of the flours used for baking is one of the most relevant points in their physical properties, since the size of the constituent particles of the flour will interfere in several quality parameters, such as the water absorption index (WAI) and, consequently, in the texture, in the sensorial quality and in the visual aspect of the bread.

Table 2. Granulometry and water absorption index (IAA) of the flour seeds studied.

\begin{tabular}{ccccc}
\hline \multirow{2}{*}{ Sieves } & Opening $(\mathbf{m m})$ & \multicolumn{3}{c}{ \% Retained Sample } \\
\cline { 3 - 5 } & & Niger & Millet & Birdseed \\
\hline 20 & 0.850 & 24.36 & 17.17 & 7.90 \\
30 & 0.600 & 34.73 & 19.94 & 19.37 \\
35 & 0.500 & 31.84 & 30.85 & 45.88 \\
50 & 0.300 & 7.84 & 16.14 & 10.25 \\
60 & 0.250 & 0.40 & 2.15 & 1.99 \\
100 & 0.150 & 0.14 & 10.22 & 1.63 \\
Base & $<0.150$ & 0.70 & 3.54 & $52.2^{2} \pm 0.5^{\mathrm{c}}$ \\
\hline
\end{tabular}

It was possible to observe that the major percentage of niger flour was retained in sieve $30,34.73 \%$, while for the millet and birdseed flours, the major percentage was retained in 
sieve $35,30.85 \%$ and $45.88 \%$, respectively. Clerice e El-Dash [36] performed a similar study with whole-meal flour produced from rice grains, which showed $63 \%$ retention in sieves 60 and 80 and $37 \%$ in sieves above 100 . In comparison with the present work, the NCPF flours had a large retention percentage of retention in sieves with larger openings (niger, millet and birdseed presented $91 \%, 68 \%$ and $73 \%$, respectively, of retention between the sieves of 20 and 35), which means that the particles obtained are of greater caliber when compared to brown rice flour but can still be considered fine solids. These differences among flours are related with the grains characteristics, especially their mechanic resistance linked to food fibers [37]. Parameters such as the grain hardness and raw material preparation before the crushing process can also interfere with the size of the flour particles [38,39], as can the method used for crushing the grain, both in relation to the equipment used and the conditions [40].

The water absorption index (WAI) of the NCFP was also determined (Table 2), being an indicator of the integrity of the starch grains and their ability to absorb water when gelatinized. In the studied samples, the WAI was $61.6 \pm 0.8 \%, 53.7 \pm 0.6 \%$ and $52.2 \pm 0.5 \%$ for niger, millet and birdseed, respectively. It can also be observed that there is a direct correlation between the WAI and the particle size of the flours, in which the WAI decreases at smaller particle sizes. Niger seeds presented higher granulometry, as previously described, also presenting a higher WAI. Compared with wheat flour, conventionally used for the preparation of bakery products, the values obtained were lower, with a water absorption index of approximately $77 \%$ [41]. Theoretically, the values obtained for the niger samples were favorable, since, according to the Instituto de Ciência e Tecnologia de Alimentos (ICTA-Institute of Science and Food Technology, Brazil), the flours that presented WAI values lower than $55 \%$ were not indicated for bread preparation but for the preparation of biscuits or in mixtures with other flours (with less water activity). With a low WAI, flours have a limited absorption capacity and, consequently, low capacity for dissolving the ingredients and binding gluten particles (necessary molecule for maintaining the bread structure). Still, flours that have a high content of dietary fiber can increase the rate of water absorption, and therefore, these two aspects together negatively affect the development of breads [37]. Millet and birdseed seeds would therefore need to be mixed with other flours for the better development of bakery products.

\subsection{Nutritional Profile and Chemical Composition of the Three Flour Seeds Samples}

The results of the nutritional composition, humidity, free sugars and organic acids for the seed flours are shown in Table 3. All samples presented low values for humidity, birdseed $(10.9 \pm 0.5 \%)$ and millet $(11.3 \pm 0.4 \%)$ being the ones with the highest humidity contents (with very close values), while niger presented the lowest value $(6.9 \pm 0.2 \%)$. Carbohydrates and ashes were the major and minor macronutrients found, respectively, in the millet and birdseed samples, except for niger, in which fat revealed the higher amounts $(37.5 \pm 0.1 \mathrm{~g} / 100 \mathrm{~g} \mathrm{dw})$. The carbohydrate $(64.9 \pm 0.3 \mathrm{~g} / 100 \mathrm{~g})$, ash $(5.7 \pm 0.3 \mathrm{~g} / 100 \mathrm{~g})$ and fat $(6.9 \pm 0.3 \mathrm{~g} / 100 \mathrm{~g})$ contents obtained for the birdseed samples were very similar to the values previously reported for birdseed from Brazil (carbohydrates-65.99 $\pm 0.2 \%$, ash $-6.31 \pm 0.13 \%$ and fat $-7.38 \pm 0.09 \%$ ) [16]. The protein content was also in accordance with that previously reported by Abdel-Aal et al. [8] in hairless birdseed cultivar CDC Maria from Canada, that also made a comparison with wheat, and it showed a relatively higher protein level (22.5 g/100 g birdseed and $17.3 \mathrm{~g} / 100 \mathrm{~g}$ wheat) [8]. The carbohydrate, fat and protein values obtained for millet seed flour were higher than those found in the literature, and for ash, the value was a bit lower. The protein, ash and carbohydrate composition values for niger were very close to those found in the literature; only the fat content $(37.5 \mathrm{~g} / 100 \mathrm{~g})$ presented a higher value $[5,17]$. 
Table 3. Proximate composition, soluble sugars and organic acid compositions in niger, millet and birdseed (mean \pm SD results expressed on a dry weight basis).

\begin{tabular}{|c|c|c|c|}
\hline & Niger & Millet & Birdseed \\
\hline Humidity (\%) & $6.9 \pm 0.2^{b}$ & $10.9 \pm 0.5^{\mathrm{a}}$ & $11.3 \pm 0.4^{\mathrm{a}}$ \\
\hline \multicolumn{4}{|l|}{ Nutritional values (g/100 g dw) } \\
\hline Fat & $37.5 \pm 0.1^{\mathrm{a}}$ & $4.3 \pm 0.1^{\mathrm{c}}$ & $6.9 \pm 0.3^{b}$ \\
\hline Proteins & $22.9 \pm 0.3^{\mathrm{a}}$ & $16.60 \pm 0.04^{b}$ & $22.5 \pm 0.4^{\mathrm{a}}$ \\
\hline Ash & $3.2 \pm 0.2^{b}$ & $2.6 \pm 0.4^{\mathrm{c}}$ & $5.7 \pm 0.3^{\mathrm{a}}$ \\
\hline Total available carbohydrates & $36.5 \pm 0.3^{c}$ & $76.5 \pm 0.3^{a}$ & $64.9 \pm 0.3^{b}$ \\
\hline Energy contribution (kcal/100 g dw) & $575 \pm 1^{\mathrm{a}}$ & $411 \pm 1^{b}$ & $412 \pm 2^{b}$ \\
\hline \multicolumn{4}{|l|}{ Soluble sugars (g/100 g dw) } \\
\hline Sucrose & $1.90 \pm 0.01^{\mathrm{a}}$ & $0.37 \pm 0.01^{\mathrm{c}}$ & $0.54 \pm 0.01^{b}$ \\
\hline \multicolumn{4}{|l|}{ Organic acids (g/100 g dw) } \\
\hline Oxalic acid & $0.324 \pm 0.003^{b}$ & $0.32 \pm 0.01^{b}$ & $0.35 \pm 0.02^{\mathrm{a}}$ \\
\hline Quinic acid & $0.050 \pm 0.003^{c}$ & $2.4 \pm 0.1^{\mathrm{b}}$ & $2.70 \pm 0.03^{\mathrm{a}}$ \\
\hline Shikimic acid & $1.04 \pm 0.04$ & nd & nd \\
\hline Fumaric acid & $0.0010 \pm 0.0001$ & $\operatorname{tr}$ & nd \\
\hline Sum & $1.41 \pm 0.05^{\mathrm{c}}$ & $2.7 \pm 0.2^{\mathrm{a}, \mathrm{b}}$ & $3.0 \pm 0.1^{\mathrm{a}}$ \\
\hline
\end{tabular}

$\mathrm{dw}-\mathrm{dry}$ weight basis; nd—not detected. Calibration curves for sugars and organic acids: sucrose $\left(y=0.977 x, R^{2}=0.999\right.$; LOD (Limit of detection $)=0.06 \mathrm{mg} / \mathrm{mL} ; \mathrm{LOQ}$ (Limit of quantification) $=0.21 \mathrm{mg} / \mathrm{mL}) ;$ oxalic acid $\left(y=9 \times 10^{6} x+45,973, R^{2}=0.9901, \mathrm{LOD}=6.3 \mu \mathrm{g} / \mathrm{mL}\right.$; $\mathrm{LOQ}=20.8 \mu \mathrm{g} / \mathrm{mL})$; quinic acid $\left(y=610,607 x+46,061, R^{2}=0.9995, \mathrm{LOD}=11.3 \mu \mathrm{g} / \mathrm{mL} ; \mathrm{LOQ}=37.6 \mu \mathrm{g} / \mathrm{mL}\right)$; shikimic acid $\left(y=7 \times 10^{7} x+\right.$ $\left.175,156, R^{2}=0.9999, \mathrm{LOD}=10.2 \mu \mathrm{g} / \mathrm{mL} ; \mathrm{LOQ}=56.5 \mu \mathrm{g} / \mathrm{mL}\right)$ and fumaric acid $\left(y=154,862 x+1 \times 10^{6}, R^{2}=0.9977, \mathrm{LOD}=42.5 \mu \mathrm{g} / \mathrm{mL}\right.$; $\mathrm{LOQ}=141.7 \mu \mathrm{g} / \mathrm{mL})$. In each row, different letters mean significant differences between species $(p<0.05)$.

Sugars interfere with various processes during the life cycle of plants, mainly storing energy to assist in basic structuring so other organic compounds can be synthesized [42]. Regarding soluble sugars, only one disaccharide, sucrose, was identified in the three samples, with niger presenting the highest value $(1.90 \pm 0.01 \mathrm{~g} / 100 \mathrm{~g})$. In another study, glucose was identified as the only soluble sugar for niger [42], but this concentration and profile may change according to the genotype and germination time of the seed [43]. For millet $(0.37 \pm 0.01 \mathrm{~g} / 100 \mathrm{~g})$ and birdseed $(0.54 \pm 0.01 \mathrm{~g} / 100 \mathrm{~g})$ flours, sucrose has also been identified as the main soluble sugar presented, being in accordance with the literature [43].

For the composition in organic acids, a total of four acids were found-namely, oxalic, quinic, shikimic and fumaric. The birdseed sample, despite presenting only two organic acids, revealed the highest total amount $(3.0 \pm 0.1 \mathrm{~g} / 100 \mathrm{~g} \mathrm{dw})$ mainly due to the presence of quinic acid $(2.70 \pm 0.03 \mathrm{~g} / 100 \mathrm{~g} \mathrm{dw})$. Millet presented a similar total amount also due to highest content in quinic acid. Several bioactive functions have been reported in organic acids-in particular, quinic acid has demonstrated therapeutic properties, including radioprotective activity, antidiabetic, anti-neuroinflammatory and antioxidant effects [44].

The composition in fatty acids was also evaluated, and the results are shown in Table 4.

Niger revealed the highest content in PUFA $(78.1 \pm 0.7 \%)$, while millet had the highest values divided between SFA and MUFA (44.97 \pm 1.01 and $44.4 \pm 0.8$, respectively); finally, for birdseed, SFA ( $52.48 \pm 0.02 \%)$ were the ones in higher amounts, followed by MUFA $(46.1 \pm 0.1 \%)$. In total, only four fatty acids were identified in the niger samples, with linoleic acid (C18:2n6) appearing in the highest percentage (78.12 $\pm 0.1 \%)$, followed by palmitic acid (C16:0; $12.1 \pm 1.4 \%)$ and stearic acid (C18:0; $9.7 \pm 1.4 \%)$. For millet, nine fatty acids were found, with oleic acid (C18:1n9) appearing in the highest percentage $(44.4 \pm 0.7 \%)$, followed by palmitic acid (C16:0; $26.1 \pm 0.4 \%)$ and linoleic acid (C18:2n6; $10.62 \pm 0.3 \%)$. Finally, the birdseed sample presented the highest amount of identified fatty acids, thirteen, with oleic acid (C18:1n9) appearing in a higher percentage $(45.59 \pm 0.11 \%)$ and in a significant concentration palmitic acid (C16:0; $34.51 \pm 0.13 \%)$. The other fatty acids identified in the three samples showed particularly low concentrations below $5 \%$ (data not shown). Even though the niger sample presented the lowest amount of fatty acids found, it can be considered the most promising due to its high content in PUFA — specifically, linoleic acid. According to some studies, an insufficient intake of polyunsaturated fatty acids is 
directly related to the increased possibility of the onset of diseases such as cardiovascular, brain, inflammatory and cancer [45].

Table 4. Fatty acid and tocopherol compositions of niger, millet and birdseed (mean $\pm \mathrm{SD}$ ).

\begin{tabular}{|c|c|c|c|}
\hline & Niger & Millet & Birdseed \\
\hline \multicolumn{4}{|c|}{$\begin{array}{c}\text { Fatty acids (relative } \\
\text { percentage, } \% \text { ) }\end{array}$} \\
\hline $\mathrm{C} 6: 0$ * & nd & $1.7 \pm 0.2$ & $1.18 \pm 0.03$ \\
\hline $\mathrm{C} 8: 0^{*}$ & nd & $0.96 \pm 0.03$ & $0.82 \pm 0.04$ \\
\hline C10:0 & nd & nd & $0.11 \pm 0.01$ \\
\hline $\mathrm{C} 11: 0$ * & nd & $0.23 \pm 0.02$ & $0.19 \pm 0.01$ \\
\hline C13:0 & nd & nd & $0.055 \pm 0.001$ \\
\hline $\mathrm{C} 14: 0$ * & nd & $0.19 \pm 0.01$ & $0.515 \pm 0.002$ \\
\hline C15:0 & nd & nd & $0.145 \pm 0.01$ \\
\hline C16:0 & $12 \pm 1^{\mathrm{c}}$ & $26.1 \pm 0.4^{b}$ & $34.5 \pm 0.1^{\mathrm{a}}$ \\
\hline $\mathrm{C} 17: 0$ * & nd & $10.4 \pm 0.6$ & $9.6 \pm 0.1$ \\
\hline C18:0 & $10 \pm 1^{b}$ & $5.4 \pm 0.2^{\mathrm{a}}$ & $5.3 \pm 0.2^{\mathrm{a}}$ \\
\hline $\mathrm{C} 18: \ln 9 *$ & nd & $44.4 \pm 0.7$ & $45.6 \pm 0.1$ \\
\hline C18:2n6 & $72.1 \pm 0.1^{\mathrm{a}}$ & $10.6 \pm 0.3^{b}$ & $1.5 \pm 0.1^{\mathrm{c}}$ \\
\hline C20:0 & $1.5 \pm 0.1$ & nd & nd \\
\hline C20:1 & nd & nd & $0.478 \pm 0.002$ \\
\hline SFA & $21.8 \pm 0.7^{\mathrm{c}}$ & $45 \pm 1^{b}$ & $52.48 \pm 0.02^{\mathrm{a}}$ \\
\hline MUFa* & nd & $44.4 \pm 0.8$ & $46.1 \pm 0.1$ \\
\hline PUFA & $78.1 \pm 0.7$ & $10.6 \pm 0.3$ & $1.5 \pm 0.1$ \\
\hline \multicolumn{4}{|c|}{ Tocopherols (mg/100 g dw) } \\
\hline$\alpha$-Tocopherol & $93.2 \pm 0.2^{\mathrm{a}}$ & $0.12 \pm 0.01^{b}$ & $0.08 \pm 0.01^{\mathrm{c}}$ \\
\hline$\beta$-Tocopherol & $1.06 \pm 0.01^{\mathrm{a}}$ & $0.07 \pm 0.01^{\mathrm{c}}$ & $0.52 \pm 0.01^{b}$ \\
\hline$\gamma$-Tocopherol & $1.2 \pm 0.3^{b}$ & $3.00 \pm 0.03^{a}$ & $0.12 \pm 0.01^{\mathrm{c}}$ \\
\hline$\delta$-Tocopherol & $0.7 \pm 0.1^{\mathrm{a}}$ & $0.67 \pm 0.03^{a}$ & $0.19 \pm 0.19^{b}$ \\
\hline Sum & $96.1 \pm 0.3^{\mathrm{a}}$ & $3.85 \pm 0.04^{b}$ & $0.91 \pm 0.01^{\mathrm{c}}$ \\
\hline
\end{tabular}

nd-not detected; dw-dry weight. Fatty acids: Caproic acid (C6:0), Caprylic acid (C8:0), Capric acid (C10:0), (C11:0), (C13:0), Myristic acid (C14:0), Pentadecanoic acid (C15:0), Palmitic acid (C16:0), Heptadecanoic acid (C17:0), Stearic acid (C18:0), Oleic acid (C18:1n9), Linoleic acid (C18:2n6), Arachidic acid (C20:0) and cis-11-Eicosenoic acid (C20:1). SFA— saturated fatty acids, MUFA-monounsaturated fatty acids and PUFA-polyunsaturated fatty acids. In each row, different letters mean significant differences between species $(p<0.05)$. Standard calibration curves for tocopherols: $\alpha$-tocopherol $\left(y=1.295 x, R^{2}=0.991\right.$; $\mathrm{LOD}=18.06 \mathrm{ng} / \mathrm{mL} ; \mathrm{LOQ}=60.20 \mathrm{ng} / \mathrm{UP}) ; \beta$-tocopherol $\left(y=0.396 x, R^{2}=0.992 ; \mathrm{LOD}=25.82 \mathrm{ng} / \mathrm{mL}\right.$ $\mathrm{LOQ}=86.07 \mathrm{ng} / \mathrm{mL}) ; \gamma$-tocopherol $\left(y=0.567 x ; R^{2}=0.991 ; \mathrm{LOD}=14.79 \mathrm{ng} / \mathrm{mL}, \mathrm{LOQ}=49.32 \mathrm{ng} / \mathrm{mL}\right)$ and $\delta$-tocopherol $\left(y=0.678 x ; R^{2}=0.992 ; \mathrm{LOD}=20.09 \mathrm{ng} / \mathrm{mL}, \mathrm{LOQ}=66.95 \mathrm{ng} / \mathrm{mL}\right)$. * -Student's $t$-test $p$-value $<0.001$.

The results obtained were confirmed by other studies, which carried out the quantification of fatty acids in niger seeds from other regions of the world. The results also highlighted linoleic, palmitic and stearic acids as the majority acids [46,47]. For millet seeds, however, the literature cites linoleic acid as the major acid, followed by oleic and palmitic acids, but still confirms the same major acids [47]. In studies carried out on birdseed, oleic and palmitic acids were also identified as the major fatty acids, but in addition to these two, the literature also cites linoleic acid as the major fatty acid $[10,48]$.

All tocopherol isoforms were detected $(\alpha, \beta, \gamma$ and $\delta)$ in niger, millet and birdseed. Likewise, niger seeds were the ones that revealed the highest amounts of tocopherol $(96.09 \pm 0.33 \mathrm{mg} / 100 \mathrm{~g} \mathrm{dw})$, mainly due to the presence of $\alpha$-tocopherol $(93.18 \pm 0.18 \mathrm{mg} / 100 \mathrm{~g} \mathrm{dw})$, followed by $\gamma$-tocopherol, $\beta$ - and $\delta$-tocopherol, which concentration totaled $2.91 \mathrm{mg} / 100 \mathrm{~g} \mathrm{dw}$. In the millet sample, $\gamma$-tocopherol was the most abundant $(3.00 \pm 0.03 \mathrm{mg} / 100 \mathrm{~g} \mathrm{dw})$. As for the birdseed sample, the $\beta$-tocopherol isoform stood out, presenting $0.52 \pm 0.01 \mathrm{mg} / 100 \mathrm{~g}$ of dry weight. The high content in tocopherol found in niger samples was in accordance with that described by Mariod et al. [49], in which they reported $90 \%$ of $\alpha$-tocopherol in the total amount of tocopherols. In a study carried out by Marini et al. [50] on niger seed oil, the transformed value of tocopherols for $\mathrm{mg} / 100 \mathrm{~g}$ ranged from 76.2 to 82.3 , in which, compared to the whole seed, it was lower 
than that described herein. However, Ramadan and Mörsel [11] reported higher values of $\beta, \gamma$ and $\delta$-tocopherol in the lipid fraction of niger seeds (33.1, 57.0 and $18.5 \mathrm{mg} / 100 \mathrm{~g}$, respectively) and lower amounts of $\alpha$-tocopherol $(86.1 \mathrm{mg} / 100 \mathrm{~g})$. Regarding millet, in previous studies carried out with millet oil, a higher content of $\gamma$-tocopherol $(48.79 \mathrm{mg} / 100 \mathrm{~g}$ oil) was described [51]. These differences could be justified by the different extraction methodologies used, as well as the different parts of the analyzed plant. Additionally, the fact that tocopherols are easily oxidized by the action of heat and presence of light and humidity can also justified these differences [52].

\subsection{Bioactivities and Phenolic Profile of the Three Flours Hydroethanolic Extracts}

The results of the antioxidant activity tests are expressed in $\mathrm{IC}_{50}(\mu \mathrm{g} / \mathrm{mL})$ values and are described in Table 5. With the two tests performed, it was possible to find the hydroethanolic extract concentration capable of inhibiting $50 \%$ of the lipid peroxidation in the lipid tissue of a pig brain (TBARS assay) and capable of protecting $50 \%$ of the erythrocytes population (from sheep blood) of the hemolytic action caused by the oxidant agent (OxHLIA assay). The analysis of the results was an indirect correlation, meaning the lower the $\mathrm{IC}_{50}$ values, greater the antioxidant capacity.

The three samples tested showed antioxidant capacity for TBARS and OxHLIA assay, except millet, which did not present hemolytic activity. Birdseed revealed the lowest $\mathrm{IC}_{50}$ values for the TBARS assay $(0.092 \pm 0.002 \mu \mathrm{g} / \mathrm{mL})$; however, it is important to note that all the samples presented lower values than the positive control Trolox, thus revealing the high potential of this samples as preventers of the lipid peroxidation. Regarding the OxHLIA assay, it is unquestionable that niger presented the highest potential, with an $\mathrm{IC}_{50}$ value of $81 \pm 5 \mu \mathrm{g} / \mathrm{mL}$.

There are few studies regarding the antioxidant capacity of these seeds. The literature describes other parts of the plants and even other type of extracts and assays-for instance, in the protein fractions, milk and oil and DPPH methodology [10,53]. Valverde et al. [53] described the protein fractions and the nutraceutical potential of birdseed that revealed high antioxidant potential in the DPPH assay. In another study performed by Salah et al. [47], they analyzed the oil fraction of birdseed, concluding it could be used as a natural antioxidant agent. The interesting properties found in the lipid fraction could contribute to minimizing the risk of cardiovascular diseases and cancer. Despite the lack of activity for the OxHLIA assay in the millet sample, this seed is very promising, having been described by Park et al. [54] with a high antioxidant potential in the DPPH assay. Likewise, as discussed by Fatima et al. [46], the use of niger seeds is also auspicious, as they have the ability to be a source of antioxidants in the human diet.

Twelve strains were used to test the antimicrobial capacity of the hydroethanolic extracts of the seed samples, six bacterial strains for antibacterial activity and six fungal strains for antifungal activity. The minimal inhibitory concentrations (MIC), minimal bactericidal concentration (MBC) and minimal fungicidal concentration (MFC) are presented in Table 5 and expressed in $\mathrm{mg} / \mathrm{mL}$. The three samples showed low MIC for both antibacterial and antifungal activity. Millet stood out as having the highest antibacterial against B. cereus and E. coli $(0.75 \mathrm{mg} / \mathrm{mL})$, and L. monocytogenes and E. cloacae $(1.5 \mathrm{mg} / \mathrm{mL})$. For antifungal activity, there were no results that stood out; however, the hydroethanolic extracts of niger and millet revealed similar MIC values for all fungal strains, and most importantly, all the of these values were lower when compared to the positive controls used (E221 and E224). These results are extremely important, as the fungal strains in question are the main cause of microbial deterioration in bakery products [55], and therefore, the introduction of these seed flours, in addition to adding value, would also work as a preserving additive to the final product itself. Other crops of plants of the Poaceae family, such as rice, corn and sorghum, are already known to have good antimicrobial activity against pathogenic microorganisms, due to their composition in phytoalexins, compounds with a high preserving capacity [56], indicating the need to introduce these flours in the food industry-more specifically, in baking. 
Finally, the hepatotoxicity results in all the hydroethanolic extracts studied did not present activity up to the maximum concentration tested $(400 \mu \mathrm{g} / \mathrm{mL})$. This means that niger, millet and birdseed seeds were not toxic against the nontumor cell line studied, a very important result in a first validation of these flours for the incorporation in food matrices without this entailing risks to the health of the final consumer.

Regarding the phenolic profile of the seeds, the chromatographic data (retention time- $-\mathrm{Tr}, \lambda_{\max }$ in the visible region, molecular ion and main $\mathrm{MS}^{2}$ fragments); tentative identification and quantification ( $\mathrm{mg} / \mathrm{g}$ extract) obtained by HPLC-DAD-ESI/MS from the niger and birdseed samples are presented in Table 6 . No phenolic compounds were identified in the millet sample at the maximum concentration tested of $50 \mathrm{mg} / \mathrm{mL}$, and, as far as the authors' knowledge, there are no previous reports on phenolic compounds in the studied samples in the literature. The two seed samples presented a very distinct phenolic profile, and in the birdseed samples, all the phenolic compounds were found in trace amounts. The niger sample presented six phenolic compounds, all derived from caffeic acid linked to other acid groups. In the birdseed sample, four phenolic compounds were identified: one caffeic acid derivative and three apigenin $C$-glycosylated derivatives. The tentative identification of compounds $\mathbf{1 n} / \mathbf{2 n}\left([\mathrm{M}-\mathrm{H}]^{-}\right.$at $\left.\mathrm{m} / z 353\right)$ and $\mathbf{4 n} / \mathbf{5 n} / \mathbf{6 n}$ ([M$\mathrm{H}]^{-}$at $m / z 515$ ) as $O$-caffeoyl and $O$-dicaffeoylquinic acids, respectively, was performed according to the hierarchical keys proposed by Clifford et al. [57,58]. Peak $\mathbf{5 n}$ was the major compound found in niger hydroethanolic extracts, with a concentration of $8.2 \pm 0.1 \mathrm{mg} / \mathrm{g}$ extract. Peak 3n ([M-H $]^{-}$at $\mathrm{m} / z$ 559) was tentatively identified as 3,9-diCOA (or 4,9-diCOA) di-caffeoyl-2,7-anhydro-3-deoxy-2-octulopyranosonic acid, based on the one previously described by Zhang et al. [59] in Erigeron breviscapus (Vaniot) Hand.-Mazz.

Relative to birdseed, peak $\mathbf{1 b}$ was tentatively identified as caffeic acid hexoside, presenting a pseudomolecular ion $[\mathrm{M}-\mathrm{H}]^{-}$at $m / z 341$ and $\mathrm{MS}^{2}$ fragments at $m / z 179$ and 161 (characteristic breaks of caffeic acid), corresponding to the loss of a hexose. The apigenin $C$-glycosylated and apigenin- $\mathrm{C}$-hexoside- $\mathrm{O}$-pentoside $\left(\mathbf{2} \mathbf{b}\right.$ and $\mathbf{3 b}$ ), $[\mathrm{M}-\mathrm{H}]^{-}$at $\mathrm{m} / z 563$ were tentatively identified according to the one previously reported by Ferreres et al. [60]. Peak $\mathbf{4 b}$ apigenin-C-6-hexoside $\left([\mathrm{M}-\mathrm{H}]^{-}\right.$at $\left.m / z 431\right)$ was identified by comparison with the available standard compound.

\subsection{Physical Parameters of Breads}

With the application of the experimental design of simplex-centroid mixtures, the special cubic models (Figure 3) are represented by Equations (1)-(5). These represent the parameters firmness $(\mathrm{g})$; specific volume $\left(\mathrm{cm}^{3} / \mathrm{g}\right)$ and color $\left(\mathrm{L}, \mathrm{a}^{*}\right.$ and $\left.\mathrm{b}^{*}\right)$, respectively. The adjusted coefficients of determination $\left(R^{2}\right)$ for the equations were $0.969055,0.978378$, $0.992596,0.808081$ and 0.947157 , respectively.

$$
\begin{gathered}
Y_{\text {Specifc vol. }}=3.543 x_{1}+3.990 x_{2}+4.353 x_{3}+1.373 x_{1} x_{2}+2.713 x_{1} x_{3}-0.020 x_{2} x_{3}+4.480 x_{1} x_{2} x_{3} \\
Y_{L}=45.617 x_{1}+62.460 x_{2}+64.620 x_{3}+12.753 x_{1} x_{2}+3.300 x_{1} x_{3}-2.880 x_{2} x_{3}-14.380 x_{1} x_{2} x_{3} \\
Y_{a *}=-2.600 x_{1}-3.043 x_{2}-3.377 x_{3}-2.700 x_{1} x_{2}-0.700 x_{1} x_{3}-1.200 x_{2} x_{3}+0.210 x_{1} x_{2} x_{3} \\
Y_{b *}=14.367 x_{1}+20.717 x_{2}+21.843 x_{3}+0.607 x_{1} x_{2}-3.340 x_{1} x_{3}-3.147 x_{2} x_{3}-20.940 x_{1} x_{2} x_{3} \\
x_{1}=5 \times[\text { niger }] ; x_{2}=5 \times[\text { millet }] ; x_{3}=5 \times[\text { birdseed }]
\end{gathered}
$$


Table 5. Antioxidant and antimicrobial activity of the hydroethanolic extracts of niger, millet and birdseed (mean \pm SD).

\begin{tabular}{|c|c|c|c|c|c|c|c|c|c|c|}
\hline & \multicolumn{2}{|c|}{ Niger } & \multicolumn{2}{|c|}{ Millet } & \multicolumn{2}{|c|}{ Birdseed } & \multicolumn{4}{|c|}{ Positive Controls } \\
\hline \multicolumn{5}{|c|}{ Antioxidant activity $\left(\mathrm{IC}_{50}\right.$ values, $\left.\mu \mathrm{g} / \mathrm{mL}\right)$} & \multicolumn{6}{|c|}{ Trolox } \\
\hline TBARS inhibition & \multicolumn{2}{|c|}{$2.31 \pm 0.03^{\mathrm{a}}$} & \multicolumn{2}{|c|}{$0.187 \pm 0.001^{b}$} & \multicolumn{2}{|c|}{$0.092 \pm 0.002^{\mathrm{c}}$} & \multicolumn{2}{|c|}{$3.73 \pm 1.9$} & \multicolumn{2}{|l|}{ - } \\
\hline OxHLIA & \multicolumn{2}{|c|}{$81 \pm 5^{*}$} & \multicolumn{2}{|c|}{ w.a. } & \multicolumn{2}{|c|}{$488 \pm 0.2 *$} & \multicolumn{2}{|c|}{$21.8 \pm 0.2$} & - & \\
\hline \multicolumn{5}{|c|}{ Antibacterial activity (MIC values, mg/mL) } & & & \multicolumn{2}{|c|}{ E211 } & \multicolumn{2}{|c|}{ E224 } \\
\hline & MIC & MBC & MIC & MBC & MIC & MBC & MIC & MBC & MIC & MBC \\
\hline Staphylococcus aureus & 3 & 6 & 3 & 6 & 3 & 6 & 4 & 4 & 1 & 1 \\
\hline Bacillus cereus & 1.5 & 3 & 0.75 & 1.5 & 1.5 & 3 & 0.5 & 0.5 & 2 & 4 \\
\hline Listeria monocytogenes & 3 & 6 & 1.5 & 3 & 3 & 6 & 1 & 2 & 0.5 & 1 \\
\hline Escherichia coli & 1.5 & 3 & 0.75 & 1.5 & 1.5 & 3 & 1 & 2 & 0.5 & 1 \\
\hline Salmonella Typhimurium & 1.5 & 3 & 1.5 & 3 & 1.5 & 3 & 1 & 2 & 1 & 1 \\
\hline Enterobacter cloacae & 3 & 6 & 1.5 & 3 & 3 & 6 & 2 & 4 & 0.5 & 0.5 \\
\hline \multicolumn{7}{|c|}{ Antifungal activity (MIC values, mg/mL) } & \multicolumn{2}{|c|}{ E211 } & \multicolumn{2}{|c|}{ E224 } \\
\hline & MIC & MFC & MIC & MFC & MIC & MFC & MIC & MFC & MIC & MFC \\
\hline Aspergillus fumigatus & 0.75 & 1.5 & 0.75 & 1.5 & 0.75 & 1.5 & 1 & 2 & 1 & 1 \\
\hline Aspergillus niger & 0.75 & 1.5 & 0.75 & 1.5 & 1.5 & 3 & 1 & 2 & 1 & 1 \\
\hline Aspergillus versicolor & 0.75 & 1.5 & 0.38 & 0.75 & 0.75 & 1.5 & 2 & 2 & 1 & 1 \\
\hline Penicillium funiculosum & 0.75 & 1.5 & 0.75 & 1.5 & 0.75 & 1.5 & 1 & 2 & 0.5 & 0.5 \\
\hline Trichoderma viride & 0.75 & 1.5 & 1.5 & 3 & 0.75 & 1.5 & 1 & 2 & 0.5 & 0.5 \\
\hline \multirow{2}{*}{\multicolumn{5}{|c|}{ Hepatotoxic activity $\left(\mathrm{GI}_{50}\right.$ values, $\left.\mu \mathrm{g} / \mathrm{mL}\right)$}} & \multicolumn{6}{|c|}{ Ellipticine } \\
\hline & , & \multicolumn{3}{|c|}{$>400$} & \multicolumn{2}{|c|}{$>400$} & \multicolumn{2}{|c|}{$3.2 \pm 0.7$} & & \\
\hline
\end{tabular}

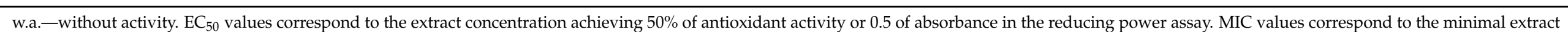

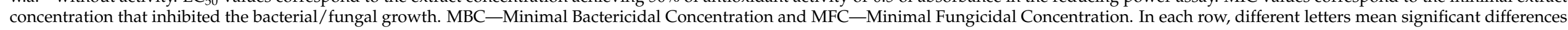
$(p<0.005) .{ }^{*}$ Student's $t$-test $p$-value $<0.001$. 


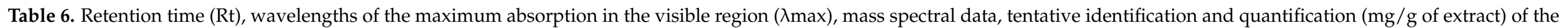
phenolic compounds present in the hydroethanolic extracts of niger and birdseed (mean $\pm S D$ ).

\begin{tabular}{|c|c|c|c|c|c|c|}
\hline Peak & Rt (min) & $\lambda \max (\mathrm{nm})$ & {$[\mathrm{M}-\mathrm{H}]^{-}(\mathrm{m} / \mathrm{z})$} & $\mathrm{MS}^{2}(\mathrm{~m} / z)$ & Tentative Identification & Quantification \\
\hline \multicolumn{7}{|c|}{ Niger } \\
\hline 1n & 6.7 & 326 & 353 & $191(100), 179(7), 173(5), 135(5)$ & 3-O-Caffeoylquinic acid & $5.87 \pm 0.01$ \\
\hline $2 n$ & 9.18 & 326 & 353 & $191(100), 179(7), 173(5), 135(5)$ & 5-O-Caffeoylquinic acid & $0.49 \pm 0.01$ \\
\hline $3 n$ & 15.02 & 326 & 559 & $\begin{array}{c}515(4), 455(2), 397(100), 379(2), 335(9), 293(9) \\
221(3), 203(7), 179(15)\end{array}$ & $\begin{array}{l}\text { 3,9-diCOA (or 4,9-diCOA) di-caffeoyl-2,7- } \\
\text { Anhydro-3-deoxy-2-octulopyranosonic acid }\end{array}$ & $2.69 \pm 0.04$ \\
\hline $4 n$ & 18.46 & 324 & 515 & $353(43), 191(39), 179(70), 173(100), 135(11)$ & 3,4-O-dicafffeoylquinic acid & $1.36 \pm 0.04$ \\
\hline $5 n$ & 19.79 & 327 & 515 & $353(21), 191(100), 179(44), 173(9), 161(5), 135(15)$ & 3,5-O-dicaffeoylquinic acid & $8.2 \pm 0.1$ \\
\hline $6 n$ & 22.77 & 327 & 515 & $353(17), 191(39), 179(65), 173(100), 161(5), 135(5)$ & $\begin{array}{c}\text { 4,5-O-dicaffeoylquinic acid } \\
\text { Total }\end{array}$ & $\begin{array}{c}5.1 \pm 0.06 \\
23.79 \pm 0.02\end{array}$ \\
\hline \multicolumn{7}{|c|}{ Birdseed } \\
\hline $1 b$ & 4.26 & 314 & 341 & $179(100), 161(10)$ & Caffeic acid hexoside & $\operatorname{tr}$ \\
\hline $2 b$ & 15.56 & 340 & 563 & $443(9), 413(100), 311(5), 293(55)$ & Apigenin- $C$-hexoside- $O$-pentoside & $\operatorname{tr}$ \\
\hline $3 b$ & 16.01 & 340 & 563 & $443(8), 413(100), 311(6), 293(49)$ & Apigenin- $C$-hexoside- $O$-pentoside & $\operatorname{tr}$ \\
\hline $4 b$ & 17.71 & 335 & 431 & $341(20), 311(100)$ & $\begin{array}{l}\text { Apigenin-6-C-hexoside } \\
\text { Total }\end{array}$ & $\begin{array}{l}\operatorname{tr} \\
\operatorname{tr}\end{array}$ \\
\hline
\end{tabular}

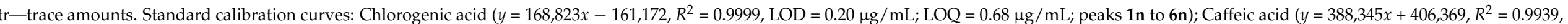

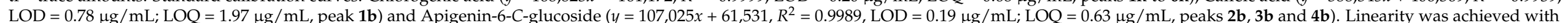

11-level calibration curves. 


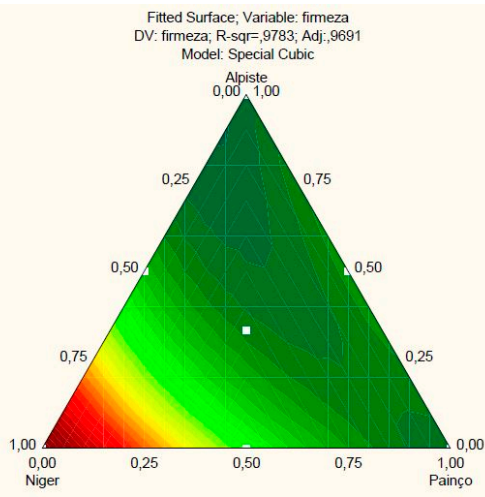

(A)

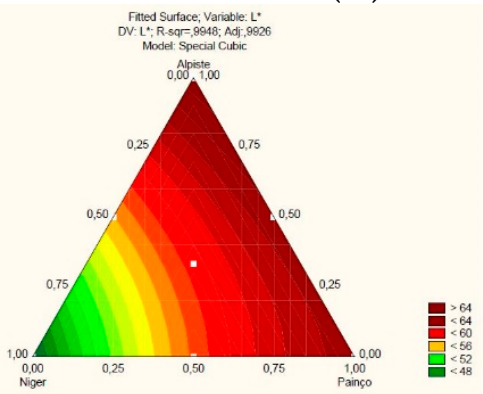

(C)

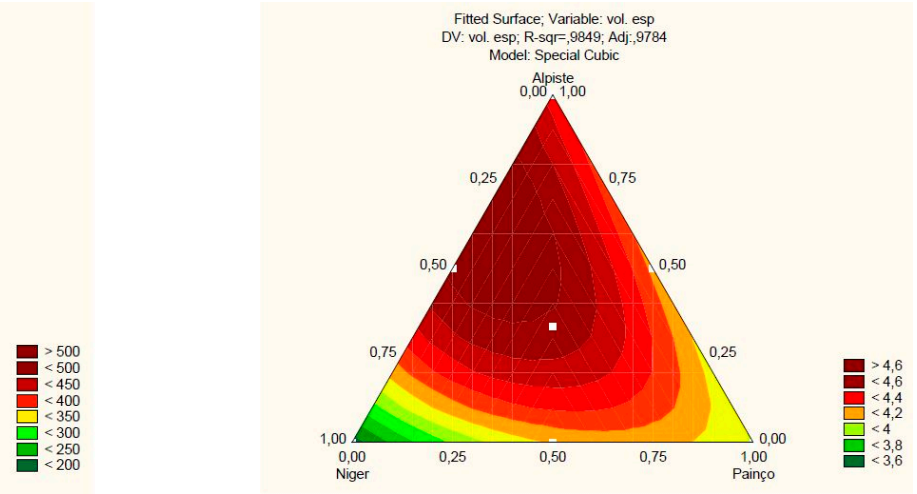

(B)

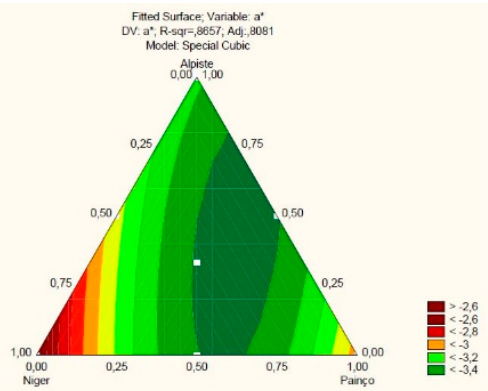

(D)

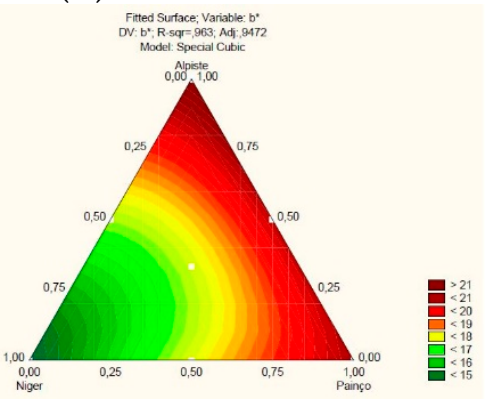

(E)

Figure 3. Area adjusted for the specific volume of bread (A); firmness (B) and color parameters for L (C), a* (D) and b* (E) of breadcrumbs containing different contents of niger, millet and birdseed. Experimental area defined by points and expressed in components.

The cubic model was used to represent the physical parameters of the breads analyzed (Figure 3). All the loaves of bread produced showed a difference in physical parameters when compared with the control loaf. The specific volume of the loaves of bread varied from 3.54 to $4.63 \mathrm{~cm}^{3} / \mathrm{g}$, values lower than the control bread $\left(5.22 \mathrm{~cm}^{3} / \mathrm{g}\right)$. There are numerous parameters that influence the quality of the bread-among them, the growth level of the bread itself, since it is directly linked to the appearance, texture and flavor of the bread [61]. The results obtained showed that the application of NCFP flours influences the volume and specific volume of the breads, lower than the control in all the modified breads. The bread with a partial substitution of $20 \%$ niger was the most affected; the bread volume decreased $32.2 \%$ compared to the control bread. The bread with $20 \%$ millet flour was the second most affected, with a decrease of $23.6 \%$ compared to the control. The sample with a $20 \%$ replacement of birdseed flour had a less drastic decrease of $16.7 \%$. According to Oliveira et al. [62], a high content of fibers in flours used in breadmaking could reduce the volume of the final product due to a higher water absorption index and lower tolerance to fermentation. The long structure of the fibers' molecules negatively affects the imprisonment of the fermentation gases (crucial to the bread volume) [63]. For that manner, the less air volume in the bread developed with $20 \%$ of niger flour could be due to the relatively high percentage of fibers and water absorption index (approximately $64 \%$ ) of niger seeds [5]. In the study performed by Chen et al. [64] was also observed a $43.7 \%$ less bread volume when substituted by NCFP flours (mango peels), correlated with a high fiber content and hydrophilic power. Some authors mention that the use of emulsifiers could help stabilize the interface between the gas and the loaf mass, so it will not lose its specific volume [65]. The partial replacement of wheat flour with alternative flours also resulted in a decrease in the specific volume in other studies carried out with partial replacements with birdseed flour and soybean flour $[8,66]$. 
The bread developed with the interaction of niger and birdseed (sample 5) showed the best performance with respect to the specific volume (Figure 3B). The higher the specific volume, the more volume the bread will have in relation to its mass, which means, the more alveoli this bread will have, and this fact can be associated with its texture due to some factors, such as the potential for air incorporation and hydrophilic characteristics of flour that correlate both factors [64]. This trend can be observed in the results obtained for bread firmness (Figure 3A), where the bread developed with 20\% niger (sample 1) had the lowest specific volume value and the highest firmness value. The color parameters of loaves of bread can be related to the ingredients itself and the processing conditions but, also, due to the Maillard reaction, develop during the breadmaking process [67]. Negative values of $a^{*}$ indicate a tendency toward green, and positive values of $b^{*}$ indicate a tendency toward yellow. The brightness decreased as redness and yellow increased; this trend was also confirmed by Protonotariou et al. [31] in their study with whole wheat flour. Sample 1 had the highest value of $a^{*}$ and the lowest value of $b^{*}$, so the formulations developed with niger tended to have less brightness. Samples 5 and 7 contributed significantly to parameter $\mathrm{a}^{*}$, and to parameter $\mathrm{b}^{*}$, the interactions in samples $4,5,6$ and 7 were significant. This study allowed to perceive that the replacement of $20 \%$ of wheat flour by NCFP flour caused significant changes in the physical characteristics and color of the developed breads. However, future studies will be needed to find the formulation that has the characteristics of firmness, specific volume and color more similar to breads made with $100 \%$ wheat flour and that, finally, meet consumer preferences.

Finally, the results of the nutritional profile and chemical characterization of the obtained breads are described in Table 7 . It is possible to observe that significant differences were obtained for all the studied parameters, with special focus on the breads developed with a partial replacement with NCFP flours always presenting higher contents than the control sample, with the exception of the total available carbohydrates, sucrose, quinic acid and MUFA contents $(80.16 \pm 0.07 \mathrm{~g} / 100 \mathrm{~g} \mathrm{dw}, 1.2 \pm 0.1 \mathrm{~g} / 100 \mathrm{~g} \mathrm{dw}, 0.07 \pm 0.01 \mathrm{~g} / 100 \mathrm{~g} \mathrm{dw}$ and $58.1 \pm 0.2 \%$, respectively). The higher amounts in fat, proteins and energy were found for sample 1 (20\% niger), which was in accordance with the results described in Table 3 , in which niger also proved to be the highest source of this molecule and with a higher energy contribution. Regarding the amounts of soluble sugars, the highest amount was found in sample 7 (mixture of niger, millet and birdseed): $0.33 \pm 0.01 \mathrm{~g} / 100 \mathrm{~g} \mathrm{dw}$. However, contrary to those described in Table 3, all the breads presented fructose and glucose in their constitutions, which could be correlated with the presence of wheat, previously reported as containing those two monosaccharides [68]. For organic acids, all the samples presented the same profile as reported in Table 3, and again, sample 7 revealed the highest amount of these compounds $(0.33 \pm 0.01 \mathrm{~g} / 100 \mathrm{~g} \mathrm{dw})$. However, regarding the fatty acids profile, sample 7 showed the highest SFA content $(62.2 \pm 1.2 \%$ ), while sample 4 (mixture of niger and millet) showed a higher percentage of PUFA (70.03 $\pm 0.07 \%)$, mainly due to the presence of linoleic acid (C18:2n6, $68.8 \pm 0.06 \%)$. This high value may be due to the presence of niger in the mixture, as this major compound was also observed in its individual characterization described in Table 4. 


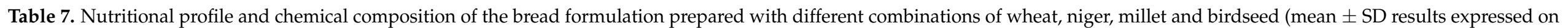
a dry weight basis).

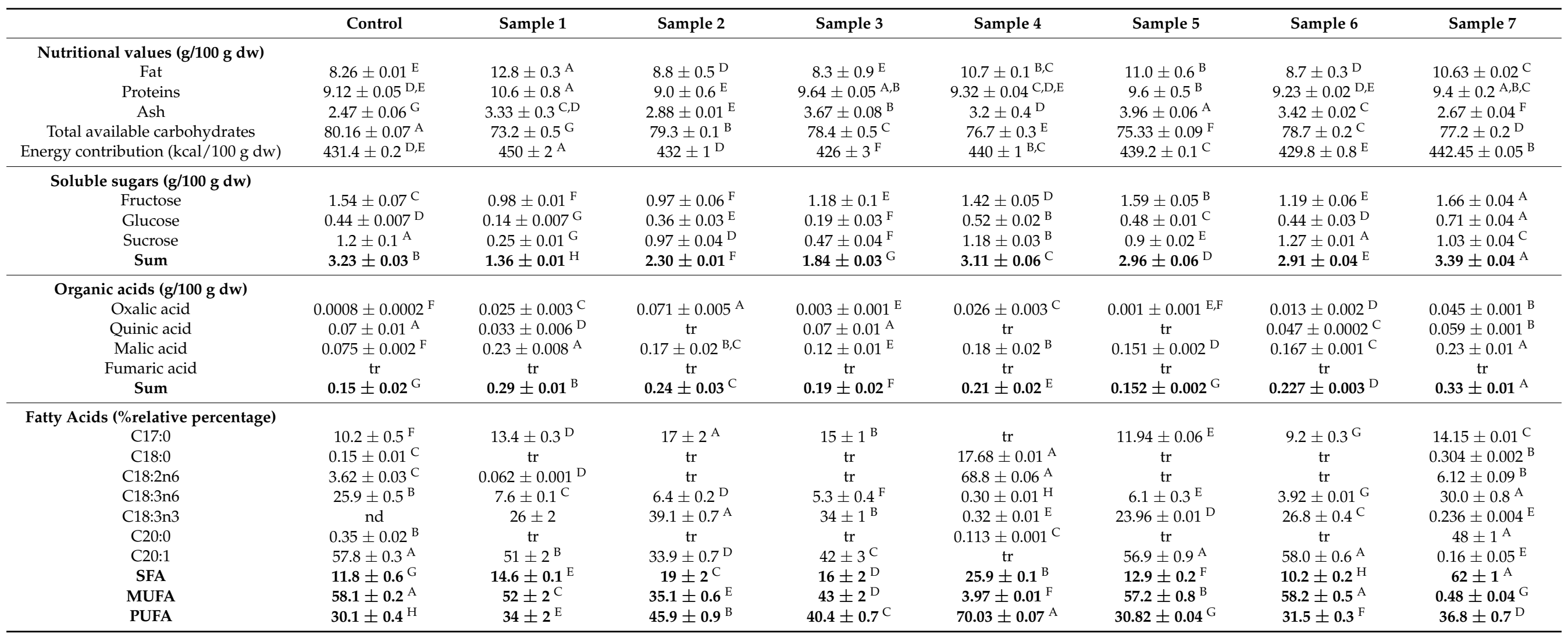

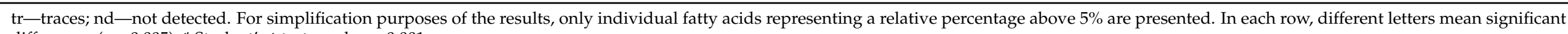
differences $(p<0.005) .{ }^{*}$ Student's $t$-test $p$-value $<0.001$. 


\section{Conclusions}

The seeds of the unconventional food plants studied in the present work can be considered as having a high nutritional value but, also, as promising sources of high added value compounds with the potential to be incorporated into food products. With the study of nutritional characterization, it could be observed that the most abundant macronutrients were carbohydrates and proteins in the seeds of millet and birdseed and the total fat content, followed by carbohydrates in niger seeds.

Regarding the study of value-added compounds such as free sugars, organic acids, tocopherols and fatty acids, it was found that sucrose was the only free sugar identified in the three samples, which is in agreement with what was previously described by the other authors. Four organic acids were also identified in the niger sample, with shikimic acid being the major compound, while, for millet and birdseed, only two organic acids, with a predominance of quinic acid, were identified. As for the fatty acid profile, the niger seeds showed a predominance of polyunsaturated fatty acids-in particular, linoleic acid (C18:2n6) - while millet and birdseed showed higher percentages of saturated and monounsaturated fatty acids, with a higher predominance for oleic acid (C18:1n9). Taking into account the profile evaluation in tocopherols, all isoforms $(\alpha, \beta, \gamma$ and $\delta$-tocopherol) were detected in the seeds, with emphasis on the high content of $\alpha$-tocopherol in the niger sample. Regarding the phenolic composition of the samples, the millet sample did not reveal any type of compound, while the niger and birdseed samples presented caffeic acid derivatives and C-glycosylated apigenin derivatives, respectively. In short, with regards to the nutritional and chemical profiles of the seed flours under study, the niger sample was the one that stood out the most, with a higher total fat content, then verified by a high percentage of PUFA, very beneficial for consumer health. The flour from this seed also presented higher levels of sugars and tocopherols (as mentioned above, mainly due to the very high concentration of $\alpha$-tocopherol).

In relation to the bioactivity assays conducted in the present study, the three samples showed a capacity to inhibit the lipid peroxidation by the TBARS assay; as for the antihemolytic capacity (OxHLIA), the millet sample did not reveal any activity. This result may be due to the fact that no phenolic compounds were detected in its composition, but correlation studies would be needed to confirm this theory. In general, all hydroethanolic extracts proved to be efficient against all the Gram-positive and Gram-negative bacteria tested but, also, against the fungal strains, presenting a bactericidal and fungicidal capacity. It should be noted that the results obtained for the antifungal activity in hydroethanolic extracts of niger and millet were lower when compared to the positive controls used (E211 and E224). These promising results may be due to the composition of molecules with a high bioactive potential, but it is not possible to establish a relationship without an in-depth study of the correlation between the compounds' bioactivity. For hepatotoxic activity, the three samples did not show activity at the maximum concentration tested, meaning that the flours of these seeds are safe for consumption and to be introduced in new food matrices or to improve existing ones.

With these results, it is possible to develop new bakery products made with NCFP flours, which, after testing the parameters of color, texture, specific volume, nutritional composition and the chemical profile of the elaborated breads, indicated that these flours have a good ability to be applied in the bakery industry without drastic changes in the physical behaviors of the elaborated products and even improve some of the nutritional and chemical characteristics.

Overall, this study allowed to present innovative results in relation to the nutritional, chemical and bioactive properties of seeds that are little-studied and consumed but with great potential to be applied in the food industry. Considering their compositions in bioactive compounds, the use of these seeds is entirely advisable in the context of a fortified diets, as they are sources of compounds of high nutritional value and with beneficial effects on the consumer's health, which is in line with what has been suggested in other recent works in the same field [69]. 
Author Contributions: Conceptualization, J.F.L., M.I.D., C.P. and M.I.; methodology, L.B., M.S. and N.C.S.; validation, L.B., M.I.D. and N.C.S.; formal analysis, M.I.D. and J.F.L.; writing-original draft preparation, M.I.D., J.F.L. and C.P. and writing-review and editing, L.B., M.I.D., N.C.S. and I.C.F.R.F. All authors have read and agreed to the published version of the manuscript.

Funding: The authors are grateful to the Foundation for Science and Technology (FCT; Portugal) for financial support through national funds FCT/MCTES to CIMO (UIDB/00690/2020), the national funding for F.C.T. and P.I. and through the institutional scientific employment program contract for C.P., M.I.D. and L.B. The authors are grateful to FEDER-Interreg España-Portugal programme for financial support through the project TRANSCoLAB 0612_TRANS_CO_LAB_2_P to ERDF through the Regional Operational Program North 2020 within the scope of the project GreenHealth-Norte-010145-FEDER-000042. This research was funded by the Serbian Ministry of Education, Science and Technological Development (Contract No. 451-03-9/2021-14/200007).

Data Availability Statement: The data presented in this study are available in this article.

Conflicts of Interest: The authors declare no conflict of interest.

\section{References}

1. Kinupp, V.F.; Barros, I.I. Levantamento de dados e divulgação do potencial das plantas alimentícias alternativas no Brasil. Hortic. Bras. 2004, 22, 17-25.

2. Leal, M.L. Conhecimento e Uso de Plantas Alimentícias Não Convencionais (PANC) no Ribeirão da Ilha-Florianópolis/sc, Florianópolis, SC.; Universidade Federal de Santa Catarina: Florianópolis, Brasil, 2015; Volume 13, pp. 1-90.

3. Tariqul Islam, A.F.M.; Chowdhury, M.G.F.; Islam, M.N.; Islam, M.S. Standardization of Bread Preparation from Soy Flour. Int. J. Sustain. Crop Prod. 2007, 2, 15-20.

4. Getinet, A.; Sharma, S.M. Niger, Guizotia abyssinica (L.f.) Cass; Plant Genetic Resources Institute: Rome, Italy, 1996; Volume 5, ISBN 9290432926.

5. Bhagya, S.; Shamanthaka Sastry, M.C. Chemical, functional and nutritional properties of wet dehulled niger (Guizotia abyssinica Cass.) seed flour. LWT Food Sci. Technol. 2003, 36, 703-708. [CrossRef]

6. Kalinova, J.; Moudry, J. Content and quality of protein in proso millet (Panicum miliaceum L.) varieties. Plant. Foods Hum. Nutr. 2006, 61, 45-49. [CrossRef]

7. CDCS Canary Seed Development Commission of Saskatchewan: Canary Seed Nutritional Factsheets. Available online: https: //www.canaryseed.ca/nutritional-factsheets.html (accessed on 15 October 2020).

8. Abdel-Aal, E.S.M.; Hucl, P.; Shea Miller, S.; Patterson, C.A.; Gray, D. Microstructure and nutrient composition of hairless canary seed and its potential as a blending flour for food use. Food Chem. 2011, 125, 410-416. [CrossRef]

9. Chen, Z.; Yu, L.; Wang, X.; Gu, Z.; Beta, T. Changes of phenolic profiles and antioxidant activity in canaryseed (Phalaris canariensis L.) during germination. Food Chem. 2016, 194, 608-618. [CrossRef]

10. Salah, H.B.; Kchaou, M.; Ben Abdallah Kolsi, R.; Abdennabi, R.; Ayedi, M.; Gharsallah, N.; Allouche, N. Chemical Composition, Characteristics Profiles and Bioactivities of Tunisian Phalaris canariensis Seeds: A Potential Source of omega-6 and omega-9 Fatty Acids. J. Oleo Sci. 2018, 67, 801-812. [CrossRef] [PubMed]

11. Fawzy Ramadan, M.; Mörsel, J.T. Phospholipid composition of niger (Guizotia abyssinica cass.) seed oil. LWT Food Sci. Technol. 2003, 36, 273-276. [CrossRef]

12. Cui, L.; Decker, E.A. Phospholipids in foods: Prooxidants or antioxidants? J. Sci. Food Agric. 2016, 96, 18-31. [CrossRef] [PubMed]

13. Pimentel, L.; Gomes, A.; Pintado, M.; Rodríguez-Alcalá, L.M. Isolation and Analysis of Phospholipids in Dairy Foods. J. Anal. Methods Chem. 2016, 2016, 9827369. [CrossRef]

14. Silva, S.D.S. Biocompounds Content in Germinated Flaxseed (Linum usitatissimum L.) and Millet (Panicum miliaceum L.); Universidade Federal de Pelotas: Pelotas, Brazil, 2014.

15. Amadou, I.; Gounga, M.E.; Le, G.W. Millets: Nutritional composition, some health benefits and processing-A review. Emir. J. Food Agric. 2013, 25, 501-508. [CrossRef]

16. Batista, R.D.; de Cássia Sousa Mendes, D.; Morais, C.C.; Thomaz, D.V.; Ramirez Ascheri, D.P.; Damiani, C.; Asquieri, E.R. Physicochemical, functional and rheological properties of fermented and non-fermented starch from canary seed (Phalaris canariensis). Food Hydrocoll. 2020, 99, 105346. [CrossRef]

17. Thatte, P.; Jyothi Lakshmi, A. Nutritional potential, bioaccessibility of minerals and antioxidant properties of niger (Guizotia abyssinicacass.) seed protein. Int. J. Food Sci. Technol. 2012, 47, 656-663. [CrossRef]

18. Germani, R.; Benassi, V.T.; Carvalho, J.L. VMétodos de Avaliação de Grão e Farinha de Trigo; EMBRAPA-CTAA; Documentos, 28; EMBRAPA-CTAA: Rio de Janeiro, Brazil, 1997.

19. Okezie, B.O.; Bello, A.B. Physicochemical and Functional Properties of Winged Bean Flour and Isolate Compared with Soy Isolate. J. Food Sci. 1988, 53, 450-454. [CrossRef]

20. AOAC Official Methods of Analysis of AOAC International, 20th ed.; AOAC International: Rockville, MD, USA, 2016. 
21. Regulation (EC) No 1169/2011 Regulation (EC) No 1169/2011 of the European Parliament and of the Council, of 25 October 2011, on the provision of food information to consumers. Off. J. Eur. Union 2011, 304, 18-63.

22. Barros, L.; Pereira, E.; Calhelha, R.C.; Dueñas, M.; Carvalho, A.M.; Santos-Buelga, C.; Ferreira, I.C.F.R. Bioactivity and chemical characterization in hydrophilic and lipophilic compounds of Chenopodium ambrosioides L. J. Funct. Foods 2013, 5, 1732-1740. [CrossRef]

23. Corrêa, R.C.G.; de Souza, A.H.P.; Calhelha, R.C.; Barros, L.; Glamoclija, J.; Sokovic, M.; Peralta, R.M.; Bracht, A.; Ferreira, I.C.F.R. Bioactive formulations prepared from fruiting bodies and submerged culture mycelia of the Brazilian edible mushroom Pleurotus ostreatoroseus Singer. Food Funct. 2015, 6, 2155-2164. [CrossRef] [PubMed]

24. Garcia, J.A.A.; Corrêa, R.C.G.; Barros, L.; Pereira, C.; Abreu, R.M.V.; Ferreira, I.C.F.R. Chemical composition and biological activities of Juçara (Euterpe edulis Martius) fruit by-products, a promising underexploited source of high-added value compounds. J. Funct. Foods 2019, 55, 325-332. [CrossRef]

25. Soković, M.; Van Griensven, L.J.L.D. Antimicrobial activity of essential oils and their components against the three major pathogens of the cultivated button mushroom, Agaricus bisporus. Eur. J. Plant. Pathol. 2006, 116, 211-224. [CrossRef]

26. Souilem, F.; Fernandes, Â.; Calhelha, R.C.; Barreira, J.C.M.; Barros, L.; Skhiri, F.; Martins, A.; Ferreira, I.C.F.R. Wild mushrooms and their mycelia as sources of bioactive compounds: Antioxidant, anti-inflammatory and cytotoxic properties. Food Chem. 2017, 230, 40-48. [CrossRef]

27. Bessada, S.M.F.; Barreira, J.C.M.; Barros, L.; Ferreira, I.C.F.R.; Oliveira, M.B.P.P. Phenolic profile and antioxidant activity of Coleostephus myconis (L.) Rchb.f.: An underexploited and highly disseminated species. Ind. Crop. Prod. 2016, 89, 45-51. [CrossRef]

28. Scheffé, H. The Simplex-Centroid Design for Experiments with Mixtures. J. R. Stat. Soc. Ser. B 1963, 25, 235-251. [CrossRef]

29. Cornell, J.A. Experiments with Mixtures: Designs, Models, and the Analysis of Mixture Data, 3rd ed.; John Wiley \& Sons: Hoboken, NJ, USA, 2011; Volume 403.

30. Calado, V.; Montgomery, D.C. Planejamento de Experimentos usando o Statística; E-papers Serviços Editoriais Ltd.a: Rio de Janeiro, Brazil, 2003.

31. Protonotariou, S.; Mandala, I.; Rosell, C.M. Jet milling effect on functionality, quality and in vitro digestibility of whole wheat flour and bread. Food Bioprocess. Technol. 2015, 8, 1319-1329. [CrossRef]

32. AACC American Association of Cereal Chemists. Approved methods: 10-05; 74-09; AACC American Association of Cereal Chemists: Saint Paul, MS, USA, 2001.

33. Perrino, E.V.; Calabrese, G. Endangered segetal species in southern Italy: Distribution, conservation status, trends, actions and ethnobotanical notes. Genet. Resour. Crop. Evol. 2018, 65, 2107-2134. [CrossRef]

34. Biswas, K.R.; Rahmatullah, M. A survey of non-conventional plants consumed during times of food scarcity in three adjoining villages of Narail and Jessore districts, Bangladesh. Am. J. Sustain. Agric. 2011, 5, 1-5.

35. Da Silva, R.F.; Ascheri, J.L.R.; Pereira, R.G.F.A.; Della Modesta, R.C. Aceitabilidade de biscoitos e bolos à base de arroz com café extrusados. Ciência Tecnol. Aliment. 2009, 29, 815-819. [CrossRef]

36. Silva Clerici, M.T.P.; El-Dash, A.A. Technological properties of pre-gelatinized rice flour obtained by thermoplastic extrusion. Cienc. Agrotecnol. 2008, 32, 1543-1550. [CrossRef]

37. Zhang, H.; Wang, H.; Cao, X.; Wang, J. Preparation and modification of high dietary fiber flour: A review. Food Res. Int. 2018, 113, 24-35. [CrossRef]

38. Greffeuille, V.; Abecassis, J.; Barouh, N.; Villeneuve, P.; Mabille, F.; Bar L'Helgouac'h, C.; Lullien-Pellerin, V. Analysis of the milling reduction of bread wheat farina: Physical and biochemical characterisation. J. Cereal Sci. 2007, 45, 97-105. [CrossRef]

39. Hrušková, M.; Švec, I.; Jirsa, O. Correlation between milling and baking parameters of wheat varieties. J. Food Eng. 2006, 77, 439-444. [CrossRef]

40. Marangoni, A.L. Potencialidade de Aplicação de Farinha de Yacon (Polymnia sonchifolia) em Produtos à Base de Cereais. Mestrado Thesis, Faculdade de Engenharia de Alimentos, Universidade Estadual de Campinas, Campinas, Brazil, 2007.

41. Manupriya, B.R.; Somashekarappa, H.M.; Patil, S.L.; Shenoy, K.B. Study of gamma irradiation effects on the physico-chemical properties of wheat flour (Triticum aestivum L.). Radiat. Phys. Chem. 2020, 172, 108693. [CrossRef]

42. Shah, D.; Sajjad, N.; Ali, R.; Nazir, N.; Hassan, S.; Shah, S. Sugar Regulates Plant Growth and Development under in Vitro Conditions. In Plant Signaling Molecules: Role and Regulation under Stressful Environments; Elsevier: Amsterdam, The Netherlands, 2019; ISBN 9780128164518.

43. Ceccaroni, D.; Alfeo, V.; Bravi, E.; Sileoni, V.; Perretti, G.; Marconi, O. Effect of the time and temperature of germination on the phenolic compounds of Triticum aestivum L. and Panicum miliaceum L. LWT 2020, 127, 109396. [CrossRef]

44. Jang, S.A.; Park, D.W.; Kwon, J.E.; Song, H.S.; Park, B.; Jeon, H.; Sohn, E.H.; Koo, H.J.; Kang, S.C. Quinic acid inhibits vascular inflammation in TNF- $\alpha$-stimulated vascular smooth muscle cells. Biomed. Pharmacother. 2017, 96, 563-571. [CrossRef] [PubMed]

45. Kraic, J.; Mihálik, D.; Klčová, L.; Gubišová, M.; Klempová, T.; Hudcovicová, M.; Ondreičková, K.; Mrkvová, M.; Havrlentová, M.; Gubiš, J.; et al. Progress in the genetic engineering of cereals to produce essential polyunsaturated fatty acids. J. Biotechnol. 2018, 284, 115-122. [CrossRef]

46. Fatima, A.; Villani, T.S.; Komar, S.; Simon, J.E.; Juliani, H.R. Quality and chemistry of niger seeds (Guizotia abyssinica) grown in the United States. Ind. Crop. Prod. 2015, 75, 40-42. [CrossRef]

47. Sarin, R.; Sharma, M.; Khan, A.A. Studies on Guizotia abyssinica L. oil: Biodiesel synthesis and process optimization. Bioresour. Technol. 2009, 100, 4187-4192. [CrossRef] 
48. Abdel-Aal, E.S.M.; Hernandez, M.; Rabalski, I.; Hucl, P. Composition of hairless canary seed oil and starch-associated lipids and the relationship between starch pasting and thermal properties and its lipids. LWT 2020, 125, 109257. [CrossRef]

49. Alnadif, A.M.; Mirghani, M.E.S.; Hussein, I. Unconventional Oilseeds and Oil Sources; Academic Press: Cambridge, MA, USA, 2017; ISBN 9780128134337.

50. Marini, F.; Magrì, A.L.; Marini, D.; Balestrieri, F. Characterization of the lipid fraction of Niger seeds (Guizotia abyssinica cass.) from different regions of Ethiopia and India and chemometric authentication of their geographical origin. Eur. J. Lipid Sci. Technol. 2003, 105, 697-704. [CrossRef]

51. Liang, S.; Yang, G.; Ma, Y. Chemical characteristics and fatty acid profile of foxtail millet bran oil. JAOCS J. Am. Oil Chem. Soc. 2010, 87, 63-67. [CrossRef]

52. Bhavsar, G.J.; Syed, H.M.; Andhale, R.R. Characterization and quality assessment of mechanically and solvent extracted Niger (Guizotia abyssinica) Seed oil. J. Pharmacogn. Phytochem. 2017, 6, 17-21.

53. Valverde, M.E.; Orona-Tamayo, D.; Nieto-Rendón, B.; Paredes-López, O. Antioxidant and antihypertensive potential of protein fractions from flour and milk substitutes from canary seeds (Phalaris canariensis L.). Plant. Foods Hum. Nutr. 2017, 72, 20-25. [CrossRef] [PubMed]

54. Park, J.S.; Lee, J.S.; Lee, J.H. Antioxidative and antimutagenic effects of Panicum miliaceum L. Korean J. Food Preserv. 2020, 27, 261-269. [CrossRef]

55. Nionelli, L.; Wang, Y.; Pontonio, E.; Immonen, M.; Rizzello, C.G.; Maina, H.N.; Katina, K.; Coda, R. Antifungal effect of bioprocessed surplus bread as ingredient for bread-making: Identification of active compounds and impact on shelf-life. Food Control 2020, 118, 107437. [CrossRef]

56. Ejike, C.E.C.C.; Gong, M.; Udenigwe, C.C. Phytoalexins from the Poaceae: Biosynthesis, function and prospects in food preservation. Food Res. Int. 2013, 52, 167-177. [CrossRef]

57. Clifford, M.N.; Knight, S.; Kuhnert, N. Discriminating between the six isomers of dicaffeoylquinic acid by LC-MSn. J. Agric. Food Chem. 2005, 53, 3821-3832. [CrossRef]

58. Clifford, M.N.; Johnston, K.L.; Knight, S.; Kuhnert, N. Hierarchical scheme for LC-MSnidentification of chlorogenic acids. J. Agric. Food Chem. 2003, 51, 2900-2911. [CrossRef]

59. Zhang, Y.; Shi, P.; Qu, H.; Cheng, Y. Characterization of phenolic compounds in Erigeron breviscapus by liquid chromatography coupled to electrospray ionization mass spectrometry. Rapid Commun. Mass Spectrom. 2007, 21, 2971-2984. [CrossRef] [PubMed]

60. Ferreres, F.; Gomes, N.G.M.; Valentão, P.; Pereira, D.M.; Gil-Izquierdo, A.; Araújo, L.; Silva, T.C.; Andrade, P.B. Leaves and stem bark from Allophylus africanus P. Beauv.: An approach to anti-inflammatory properties and characterization of their flavonoid profile. Food Chem. Toxicol. 2018, 118, 430-438. [CrossRef]

61. Chen, Y.; Zhao, L.; He, T.; Ou, Z.; Hu, Z.; Wang, K. Effects of mango peel powder on starch digestion and quality characteristics of bread. Int. J. Biol. Macromol. 2019, 140, 647-652. [CrossRef]

62. Moreira, T.; Pirozi, R.; Borges, S.; Duke, U. Elaboração de pão de sal utilizando farinha mista de trigo e linhaça. Aliment. Nutr. Araraquara 2007, 18, 141-150.

63. Aparecida, D.; Vilhalva, A.; Soares, M.; Júnior, S.; Melo, C.; De Moura, A.; Caliari, M.; Anders, T.; Souza, C.; Alves, F.; et al. Aproveitamento da farinha de casca de mandioca na elaboração de pão de forma. Rev. Inst. Adolfo Lutz 2011, 70, 514-535.

64. Sciarini, L.S.; Ribotta, P.D.; León, A.E.; Pérez, G.T. Influence of Gluten-free Flours and their mixtures on batter properties and bread quality. Food Bioprocess. Technol. 2010, 3, 577-585. [CrossRef]

65. Tebben, L.; Shen, Y.; Li, Y. Improvers and functional ingredients in whole wheat bread: A review of their effects on dough properties and bread quality. Trends Food Sci. Technol. 2018, 81, 10-24. [CrossRef]

66. Kohajdová, Z.; Karovičová, J. Nutritional value and baking applications of spelt wheat. Acta Sci. Pol. Technol. Aliment. 2008, 7, 5-14.

67. Shen, Y.; Chen, G.; Li, Y. Bread characteristics and antioxidant activities of Maillard reaction products of white pan bread containing various sugars. LWT 2018, 95, 308-315. [CrossRef]

68. Lefebvre, D.; Gabriel, V.; Vayssier, Y.; Fontagné-Faucher, C. Simultaneous HPLC determination of sugars, organic acids and ethanol in sourdough process. LWT Food Sci. Technol. 2002, 35, 407-414. [CrossRef]

69. Perrino, E.V.; Perrino, P. Crop wild relatives: Know how past and present to improve future research, conservation and utilization strategies, especially in Italy: A review. Genet. Resour. Crop. Evol. 2020, 67, 1067-1105. [CrossRef] 